\title{
An Iatrogenic Model of Brain Small-Vessel Disease: Post-Radiation Encephalopathy
}

\author{
Rita Moretti ${ }^{1,2}$ and Paola Caruso ${ }^{1,2, *}$ \\ 1 Department Medical, Surgical, Health Sciences, University of Trieste, Cattinara Hospital, Strada di Fiume, \\ 447, 34149 Trieste, Italy; moretti@units.it \\ 2 Neurological Clinic, Department of Internal Medicine and Neurology, University of Trieste, \\ Cattinara Hospital, Strada di Fiume, 447, 34149 Trieste, Italy \\ * Correspondence: paolacaruso83@gmail.com; Tel.: +39-040-3994569
}

Received: 22 July 2020; Accepted: 1 September 2020; Published: 5 September 2020

\begin{abstract}
We studied 114 primitive cerebral neoplasia, that were surgically treated, and underwent radiotherapy (RT), and compared their results to those obtained by 190 patients diagnosed with subcortical vascular dementia (sVAD). Patients with any form of primitive cerebral neoplasia underwent whole-brain radiotherapy. All the tumor patients had regional field partial brain RT, which encompassed each tumor, with an average margin of $2.6 \mathrm{~cm}$ from the initial target tumor volume. We observed in our patients who have been exposed to a higher dose of RT (30-65 Gy) a cognitive and behavior decline similar to that observed in SVAD, with the frontal dysexecutive syndrome, apathy, and gait alterations, but with a more rapid onset and with an overwhelming effect. Multiple mechanisms are likely to be involved in radiation-induced cognitive impairment. The active site of RT brain damage is the white matter areas, particularly the internal capsule, basal ganglia, caudate, hippocampus, and subventricular zone. In all cases, radiation damage inside the brain mainly focuses on the cortical-subcortical frontal loops, which integrate and process the flow of information from the cortical areas, where executive functions are "elaborated" and prepared, towards the thalamus, subthalamus, and cerebellum, where they are continuously refined and executed. The active mechanisms that RT drives are similar to those observed in cerebral small vessel disease (SVD), leading to sVAD. The RT's primary targets, outside the tumor mass, are the blood-brain barrier (BBB), the small vessels, and putative mechanisms that can be taken into account are oxidative stress and neuro-inflammation, strongly associated with the alteration of NMDA receptor subunit composition.
\end{abstract}

Keywords: radiation-induced cognitive impairment; small vessel disease; oxidative stress and neuro-inflammation

\section{Introduction}

Ions derived from electrons' ejection from either atoms or molecules, secondary to different stresses such as high temperature, electrical discharges, or electromagnetic and nuclear radiation $[1,2]$, are the basis for radiation.

Radiation-induced brain injury is classified as acute, early delayed (subacute), and late-delayed reactions based on the timing of the onset of symptoms [3-5]. Acute injury, occurring $48 \mathrm{~h}$ to several weeks after the end of the radiotherapy cure, is characterized by general symptoms such as fatigue and sleepiness, drowsiness, and central symptoms such as memory loss and local, and not irreparable, demyelination. On the other hand, the definite injuries occur from six months up to several years after radiotherapy; the demyelination is overwhelming and irreversible and ends in white matter necrosis [6]. The late-onset radiotherapy (RT) damages are irreversible and often 
fatal, especially when patients undergo chemotherapy together with radiation, (whole-brain RT (usually 4000-4500 cGy) plus a focal tumor boost [7,8]; the potentiating effect of nitrosoureas, chemotherapy on the neurotoxic effect of RT [9,10]; with methotrexate [11], temozolomide [12], or rituximab [13]). Although there have been significant developments in understanding the pathophysiological mechanisms of radiotherapy-induced brain damage, limited information on the etiology of radiation-induced damage to healthy brain tissue is currently disposable.

Radiation causes damages directly on DNA strands and on RNA and destroying all the cellular bilayers, by inducing calcium inflow, stimulating apoptosis by mechanisms not completely understood [14,15]. Preclinical molecular studies have clarified that radio-induced brain damage is correlated with radiation exposure, the total administered dose, dose per fraction, and the duration of irradiation [16].

Many studies have failed to acquire a safety dose/brain-volume-target ratio, and the general acquired accepted data conclude that the maximally tolerated dose for boards of maximum diameter comprised in between 31 and $40 \mathrm{~mm}$ should be $15 \mathrm{~Gy}$, whereas it could be of 18 Gy for boards of diameter in between 21 and $30 \mathrm{~mm}$. The main results are, in clinical practice, wholly discordant, and if anything definite has been written, due to the disproportionate differences in the definitions of the target volume, the determination of the toxicity, it is necessary to protect critical brain structures from the RT beams, depending on the type and length of clinical follow-up [17]. The European Platform of Cancer Research (EORTC) Radiotherapy Cooperative Group, the EORTC Brain Tumor Group, and the Brain Tumor Working Party of the MRC (UK) participated in this long determining study [17]. The results were discordant, since the publication of the interim results, in which two factions were outlined: one which supported and the one which condemned RT. The non-believers in RT supported RT's side-effects and did not justify a precocious RT, suggesting that delayed RT might be equally effective $[12,17]$.

This is why new techniques have been implemented to ameliorate RT toxicity risks, usually given by external beam RT. Many centers now possess many different other potential systems, such as intensity-modulated radiation therapy (IMRT). This technique permits to shape and adjust beams' intensity and direction. The potential benefit is obvious, i.e., the total or the partial spearing of the optic nerve, the brain stem, and the pituitary gland. On the other hand, this procedure permits to implement radiation intensity toward the tumor target. Stereotactic radiation therapy is external beam radiation directed through the tumor, also called the treatment field, via a 3D model, previously created by CT or more often via an MRI picture. Finally, the more non-conventional and modern technique is conformal proton beam radiation. Protons are charged particles and have a very rapid energy loss in the last few millimeters of penetration. Therefore, it is possible that a sharply localized peak of dose, known as the Bragg peak, is directly related to the initial energy of protons. Therefore, the desired dose can thus be precisely placed, with limited radiation dispersion. Unfortunately, proton beams are not easily obtained and are quite expensive.

Nevertheless, one of the most recent works on the topic by EORTC leaves us in a still open debate [18], and two studies showed that the quality of life after brain RT decreases and suggests tumor consequences as for the RT side-effects [19,20]. Irreversible cognitive impairment as an RT consequence is, unfortunately, well demonstrated by many different studies [11,12,21-23].

\section{Our Recent Data}

\subsection{Subjects}

We expanded a recently published study [12]; we enclosed the results of 114 cases (45.2 \pm 3.7 years old) of primitive cerebral neoplasia, surgically treated; all of them underwent radiotherapy (Group A). They were enrolled by the Complex Neurological Case Section, to be studied and then prepared for neurosurgery. Patients with focal Broca or Wernicke's area brain tumors were excluded due to major, confounding linguistic impairment. 
Control subjects were 190 men and women, $(72.3 \pm 2.3$ years old) (group B), diagnosed with subcortical vascular dementia (sVAD) entering the Neurological Unit of the University of Trieste. Their Mini-Mental State Examination (MMSE) scores were of at least 16, and they satisfied the fifth edition of the Diagnostic and Statistical Manual of Mental Disorders (DSM-V) for dementia, recruited from 1 June 2010 to 1 June 2016. They satisfied the criteria for probable VaD following the NINDS-AIREN criteria [24]. A patient was diagnosed with subcortical VaD (sVaD) when the CT/MRI scan showed moderate to severe ischemic white matter changes [25-32] and at least one lacunar infarct. All patients underwent a standardized baseline assessment that included a detailed history, a physical examination, laboratory tests, and neuropsychological assessment. Visits were scheduled to occur every three months after the beginning of the RT treatment and were equivalent for both groups.

This study was conducted following the Declaration of Helsinki and the Ethics Guidelines of the Comitato Etico Ospedaliero Univeristario Regionale (CEUR), point 4. Written informed consent was obtained from all participants or their responsible caregivers before the study.

\subsection{Methods}

We followed our previously published criteria of testing selection [11,12], even though many different schemata have been proposed for a neuropsychological evaluation of RT encephalopathy $[33,34]$. This study's primary purpose remained to compare the executive behavior and motor scores in the two studied groups, one of de novo RT-treated patients and one of sVAD patients. To implement the study of executive functions we employed MMSE [35], Digit Span Forward and Backward [36], a three-minute phonological and semantic fluency test [37], as well as mental and written calculation test [38]; behavioral scales were chosen for the Apathy Score (AES-S and C) [39] and the Behavioral Pathology in AD Rating Scale, BEHAVE-AD [40]. We studied the gait and equilibrium with the Tinetti scale [41]. Handedness was determined by Briggs and Nebes test [42].

\subsection{Statistical Analysis}

Statistical analyses were performed using SAS ${ }^{\circledR}$ software (version 16.2 SAS ${ }^{\circledR}$ Software Inc, Cary, NC, USA). The difference in baseline characteristics between the RT and sVAD patients was assessed by the ANOVA test for the categorical variables; in case the ANOVA results were found to be significant, the multiple comparison analysis was also done by the Tukey test, to examine those groups which were significantly different for each other. Between group comparisons of changes from baseline were tested using the Marginal Homogeneity Test. Results are presented with standard deviations, and $p$-values are provided where appropriate.

\subsection{Results}

We followed 114 cases of primitive cerebral neoplasia (Group A) (Table 1). They underwent neurosurgery; the surgical operations were radical in $27 \%$ of cases; $32 \%$ of cases could be considered partially efficacious; and in $40 \%$ of cases surgery could be considered a stereotaxic biopsy. The final histological examination concluded 44 cases of glioblastoma multiforme; 26 cases of cerebral lymphomas (mild- or low-grade differentiation); 19 cases of grade- 2 gliomas; 8 cases of craniopharyngiomas; 12 cases of II-III grade-astrocytomas; and 5 cases described as anaplastic patterns.

All of Group A was submitted to radiotherapy: the patients underwent fractionated external beam radiation therapy (from 20 to $65 \mathrm{cGy}$ ). Patients with any form of primitive cerebral neoplasia underwent WBRT: radiotherapists used the regional fields partial brain, encompassing each tumor, with an average margin of $2.6+0.7 \mathrm{~cm}$ from the initial target tumor volume. Therefore, in this study, we did not consider the size of the tumor/radiation field ratio.

We chose 190 sVAD patients which were Group B. All the patients could be thoroughly studied (mean age $72.3 \pm 2.3$ years). The diagnosis was based on historical information and neuropsychological assessment and was supported by structural (CT or MRI) imaging findings. The subsequent follow-up 
of subjects reinforced the clinical diagnoses in all cases. A neurologist (RM) revised all the imaging, employing the CT scans [29] or the MRI imaging scales [27,28,31,32] in sVAD patients.

Table 1. Baseline characteristics of the Group A patients.

\begin{tabular}{cc}
\hline Group A & \\
\hline Number of cases & 114 \\
Mean age & $45.2 \pm 3.7$ \\
Handedness Briggs and Nebes Test [42] & 22.4 \\
Educational level & Diagnosis \\
& $17.7+1.2$ years of school \\
& 44 glioblastoma multiforme \\
& differentiation \\
& 19 grade-2 gliomas \\
& 8 craniopharyngiomas \\
& 12 II-III grade-astrocytomas \\
& 5 anaplastic patterns. \\
\hline
\end{tabular}

All the surgery patients underwent two preliminary neuropsychological tests to identify an eventual decay of cognitive performances due to the tumor mass localization or the consequence of neurosurgery.

Then, both groups were examined at recruitment after radiotherapy, 3, 6, and 12 months after. At the end of the follow-up process (12.2 + 4.6 months), Group A characteristics were reported in Table 2. Twenty-six patients underwent a total RT dose $<30 \mathrm{~Gy}$; their histological profile could be summarized as eight craniopharyngiomas, ten grade- 2 gliomas, and eight grade- 2 astrocytomas. All of them underwent CT. Forty-four patients underwent a total RT dose of 30-45 Gy; their histological profile resulted as eighteen glioblastoma multiforme, ten cerebral lymphomas, nine grade-2-gliomas, four grade-3-astrocytomas, and three anaplastic patterns. Six patients underwent methotrexate (MTX) simultaneously, six patients underwent Rituximab and six underwent Temozolomide. Finally, forty-four patients underwent a total RT dose comprised between 45 and $65 \mathrm{~Gy}$. Their histology was composed of twenty-six glioblastoma multiforme, sixteen cerebral lymphomas, and two anaplastic patterns. Ten patients underwent MTX treatment at the same time, 16 underwent Rituximab, and 26 with Temozolomide.

Table 2. Radiotherapy amounts.

\begin{tabular}{|c|c|c|c|}
\hline & Dose of Radiation & Histology & $\mathrm{CT}$ \\
\hline 26 patients & $<30 \mathrm{~Gy}$ & $\begin{array}{l}8 \text { craniopharingiomas } \\
10 \text { grade } 2 \text { gliomas } \\
8 \text { grade } 2 \text { astrocytomas }\end{array}$ & Any \\
\hline 44 patients & 30-45 Gy & $\begin{array}{c}18 \text { glioblastoma multiforme } \\
10 \text { cerebral lymphoma } \\
9 \text { grade } 2 \text { gliomas } \\
4 \text { grade } 3 \text { astrocytomas } \\
3 \text { anaplastic pattern }\end{array}$ & $\begin{array}{c}6 \text { MTX } \\
6 \text { Rituximab } \\
6 \text { Temozolamide }\end{array}$ \\
\hline 44 patients & 45-65 Gy & $\begin{array}{c}26 \text { glioblastoma multiforme } \\
16 \text { cerebral lymphomas } \\
2 \text { anaplastic patterns }\end{array}$ & $\begin{array}{c}10 \text { MTX } \\
16 \text { Rituximab } \\
\text { 26 Temozolamide }\end{array}$ \\
\hline
\end{tabular}

Twelve patients (45-65 Gy RT) died during the follow-up, and they were not taken into account for the final statistical analysis. A total of 102 patients were thoroughly studied. All the oncological patients underwent MRI scans after RT. The increase in white matter hyper-intensities on the T2-weighted 
images, markedly on the periventricular regions, was consistently evident from 30-45 to 45-65 Gy and were localized mainly in the internal capsule, the paraventricular frontal and basal ganglia areas.

At baseline, sVAD patients did worse in digit span, analogies, and semantic fluency (see Table 3).

Table 3. A synopsis of the scores obtained by the two groups at baseline (Group A, before radiotherapy (RT)).

\begin{tabular}{cccccc}
\hline Variables & Group A & Group B & F CHI2 Value & DF & $p$-Value \\
\hline MMSE & $28.3 \pm 2.2$ & $27.3 \pm 2.3$ & 0.97 & 2.88 & 0.56 \\
Phon. Fluency (items produced) & $45.6 \pm 2.4$ & $39.3 \pm 3.5$ & 0.98 & 2.34 & 0.67 \\
Sem. Fluency (items produced) & $32.1 \pm 2.5$ & $27.3 \pm 2.3$ & 0.87 & 2.45 & $<0.05$ \\
Mental calculation (correct/15) & $11.4 \pm 2.3$ & $9.8 \pm 1.3$ & 0.89 & 2.34 & 0.78 \\
Analogies (correct/26) & $24.5 \pm 5.6$ & $19.3 \pm 2.4$ & 0.89 & 2.45 & $<0.01$ \\
Digit span forward & $6.7 \pm 2.3$ & $4.5 \pm 2.1$ & 0.78 & 2.36 & $<0.01$ \\
Digit span backward & $5.9 \pm 1.2$ & $4.1 \pm 1.2$ & 0.87 & 2.56 & $<0.01$ \\
BEHAVE-AD & $4.5 \pm 7.6$ & $3.7 \pm 0.3$ & 0.89 & 2.34 & 0.98 \\
AES-S & $10.3 \pm 1.1$ & $12.1 \pm 5.3$ & 0.86 & 2.55 & 0.87 \\
AES-C & $9.2 \pm 2.1$ & $13.9 \pm 1.2$ & 0.98 & 2.33 & 0.89 \\
\hline
\end{tabular}

Twenty-six patients who received a cumulative dose of radiation $<30$ cGy were compared to sVAD patients. Results demonstrated that sVAD patients after one year from the diagnosis were worse in phonological and semantic fluency, analogies, digit span backward, apathy (Table 4).

Table 4. A synopsis of the scores obtained by the patients of Group A who underwent to a total dose of $<30$ cGy, at 12 months.

\begin{tabular}{cccccc}
\hline Variables & $\begin{array}{c}\text { Group A } \\
\text { Pts }<\mathbf{3 0} \text { Gy }\end{array}$ & Group B & F CHI2 Value & DF & $p$-Value \\
\hline MMSE & $25.9 \pm 1.7$ & $26.34 \pm 2.2$ & 0.97 & 2.88 & 0.56 \\
Phon. Fluency (items produced) & $40.1 \pm 2.2$ & $31.67 \pm 2.4$ & 0.98 & 2.45 & $<0.01$ \\
Sem. Fluency (items produced) & $34.5 \pm 1.23$ & $24.4 \pm 1.4$ & 0.81 & 2.45 & $<0.01$ \\
Mental calculation (correct/15) & $12.3 \pm 1.4$ & $11.8 \pm 1.3$ & 0.84 & 2.34 & 0.78 \\
Analogies (correct/26) & $19.2 \pm 1.1$ & $24.5 \pm 5.6$ & 0.85 & 2.53 & $<0.05$ \\
Digit span forward & $6.7 \pm 0.4$ & $6.8 \pm 2.3$ & 0.78 & 2.36 & 0.67 \\
Digit span backward & $4.65 \pm 0.7$ & $6.1 \pm 0.3$ & 0.85 & 2.52 & $<0.05$ \\
BEHAVE-AD & $3.1 \pm 1.4$ & $2.7 \pm 0.4$ & 0.89 & 2.37 & 0.98 \\
AES-S & $9.5 \pm 1.4$ & $12.1 \pm 0.4$ & 0.86 & 2.55 & $<0.01$ \\
AES-C & $12.1 \pm 1.4$ & $15.9 \pm 4.3$ & 0.98 & 2.33 & $<0.05$ \\
Tinetti Gait & $13.1 \pm 0.1$ & $10.1 \pm 0.1$ & 0.89 & 2.37 & 0.98 \\
Tinetti Equilibrium & $10.2 \pm 1.1$ & $10.2 \pm 1.1$ & 0.82 & 2.12 & 0.45 \\
Tinetti Total score & $23.3 \pm 1.2$ & $20.3 \pm 1.2$ & 0.84 & 2.01 & 0.76 \\
\hline
\end{tabular}

Forty patients who received a total dose comprised between 30 and 45 cGy manifested a global slowness of the cognitive process. They did worse than the sVAD Group after 12 months in phonological fluency tasks, analogies, and digit span scores. Their behavior deteriorated more rapidly than the sVAD group, in terms of apathy scores (Table 5).

Table 5. A synopsis of the scores obtained by the patients of Group A who underwent to a total dose of 30-45 Gy, at 12 months.

\begin{tabular}{cccccc}
\hline Variables & $\begin{array}{c}\text { Group A } \\
\text { Pts 30-45 Gy }\end{array}$ & Group B & F CHI2 Value & DF & $p$-Value \\
\hline MMSE & $26.1 \pm 1.2$ & $26.34 \pm 2.2$ & 0.78 & 2.88 & 0.59 \\
Phon. Fluency (items produced) & $28.3 \pm 2.6$ & $31.67 \pm 2.4$ & 0.98 & 2.45 & $<0.05$ \\
Sem. Fluency (items produced) & $26.7 \pm 2.9$ & $24.4 \pm 1.4$ & 0.81 & 2.45 & $<0.05$ \\
Mental calculation (correct/15) & $6.7 \pm 1.2$ & $11.8 \pm 1.3$ & 0.84 & 2.34 & 0.78 \\
\hline
\end{tabular}


Table 5. Cont.

\begin{tabular}{cccccc}
\hline Variables & $\begin{array}{c}\text { Group A } \\
\text { Pts 30-45 Gy }\end{array}$ & Group B & F CHI2 Value & DF & $p$-Value \\
\hline Analogies (correct/26) & $17.9 \pm 4.1$ & $24.5 \pm 5.6$ & 0.85 & 2.53 & $<0.01$ \\
Digit span forward & $4.9 \pm 1.4$ & $6.8 \pm 2.3$ & 0.77 & 2.36 & $<0.05$ \\
Digit span backward & $4.1 \pm 2.2$ & $6.1 \pm 0.3$ & 0.85 & 2.52 & $<0.05$ \\
BEHAVE-AD & $5.84 \pm 3.89$ & $2.7 \pm 0.4$ & 0.89 & 2.78 & $<0.05$ \\
AES-S & $19.4 \pm 1.4$ & $12.1 \pm 0.4$ & 0.86 & 2.54 & $<0.01$ \\
AES-C & $21.5 \pm 1.4$ & $15.9 \pm 4.34$ & 0.98 & 2.31 & $<0.01$ \\
Tinetti Gait & $12.4 \pm 0.2$ & $10.1 \pm 0.1$ & 0.89 & 2.37 & 0.98 \\
Tinetti Equilibrium & $10.8 \pm 0.7$ & $10.2 \pm 1.1$ & 0.82 & 2.12 & 0.45 \\
Tinetti Total score & $23.2 \pm 0.3$ & $20.3 \pm 1.2$ & 0.84 & 2.01 & 0.76 \\
\hline
\end{tabular}

Thirty-six patients underwent high doses of radiation therapy (45-65 Gy) and presented at 12 months a significant deterioration of all the tested performances (Table 6).

Table 6. A synopsis of the scores obtained by the patients of Group A who underwent to a total dose 45-65 Gy, at 12 months.

\begin{tabular}{cccccc}
\hline Variables & $\begin{array}{c}\text { Group A } \\
\text { Pts 45-65 Gy }\end{array}$ & Group B & F CHI2 Value & DF & $p$-Value \\
& $19.0 \pm 2.7$ & $26.34 \pm 2.2$ & 0.78 & 2.88 & $<0.01$ \\
MMSE & $14.5 \pm 1.7$ & $31.67 \pm 2.4$ & 0.98 & 2.45 & $<0.01$ \\
Phon. Fluency (items produced) & $13.2 \pm 1.5$ & $24.4 \pm 1.4$ & 0.81 & 2.45 & $<0.01$ \\
Sem. Fluency (items produced) & $4.1 \pm 0.2$ & $11.8 \pm 1.3$ & 0.84 & 2.31 & $<0.01$ \\
Mental calculation (correct/15) & $12.2 \pm 0.6$ & $24.5 \pm 5.6$ & 0.88 & 2.35 & $<0.01$ \\
Analogies (correct/26) & $4.0 \pm 0.8$ & $6.8 \pm 2.3$ & 0.77 & 2.36 & $<0.05$ \\
Digit span forward & $3.6 \pm 0.3$ & $6.1 \pm 0.3$ & 0.85 & 2.52 & $<0.01$ \\
Digit span backward & $5.7 \pm 4.7$ & $2.7 \pm 0.4$ & 0.89 & 2.78 & $<0.05$ \\
BEHAVE-AD & $21.8 \pm 3.4$ & $12.1 \pm 0.4$ & 0.86 & 2.54 & $<0.01$ \\
AES-S & $25.2 \pm 2.2$ & $15.9 \pm 4.34$ & 0.98 & 2.31 & $<0.01$ \\
AES-C & $9.1 \pm 0.1$ & $10.1 \pm 0.1$ & 0.89 & 2.37 & 0.067 \\
Tinetti Gait & $7.2 \pm 1.4$ & $10.2 \pm 1.1$ & 0.82 & 2.12 & $<0.05$ \\
Tinetti Equilibrium & $15.3 \pm 1.5$ & $20.3 \pm 1.2$ & 0.84 & 2.01 & $<0.05$ \\
Tinetti Total Score & & & & &
\end{tabular}

A marginal homogeneity test revealed a significant decrease in the performances in all the scores when compared to the higher to the lower RT doses (Table 7).

Table 7. Marginal homogeneity test for multiple comparison (for the first row: the first $p$-value is the comparison of $45-65$ Gy vs. $<30$ Gy; the second is the comparison of 30-45 Gy vs. $<30$ Gy; for the second row, the $p$-value is the comparison of $30-45$ Gy vs. $45-65$ Gy).

\begin{tabular}{|c|c|c|c|}
\hline Variables & $\mathrm{RT}<30 \mathrm{~Gy}$ & RT 30-45 Gy & RT 45-65 Gy \\
\hline MMSE & $\begin{array}{c}24.2 \pm 1.6 \\
p<0.05 ; p<0.01\end{array}$ & $\begin{array}{c}21.3 \pm 1.2 \\
p<0.01\end{array}$ & $12.1 \pm 2.7$ \\
\hline Phon. Fluency & $\begin{array}{c}35.2 \pm 2.2 \\
p<0.01 ; p<0.01\end{array}$ & $\begin{array}{c}19.7 \pm 2.6 \\
p<0.01\end{array}$ & $7.5 \pm 1.7$ \\
\hline Sem. Fluency (items produced) & $\begin{array}{c}29.1 \pm 1.3 \\
p<0.01 ; p<0.01\end{array}$ & $\begin{array}{c}15.3 \pm 2.9 \\
p<0.01\end{array}$ & $9.2 \pm 1.5$ \\
\hline Mental calculation (correct/15) & $\begin{array}{c}10.5 \pm 1.4 \\
p<0.01 ; p<0.01\end{array}$ & $\begin{array}{l}5.2 \pm 1.2 \\
p<0.01\end{array}$ & $2.3 \pm 0.2$ \\
\hline Analogies (correct/26) & $\begin{array}{c}18.6 \pm 1.1 \\
p<0.01 ; p<0.01\end{array}$ & $\begin{array}{l}9.7 \pm 4.1 \\
p<0.05\end{array}$ & $6.2 \pm 0.6$ \\
\hline
\end{tabular}


Table 7. Cont.

\begin{tabular}{|c|c|c|c|}
\hline Variables & $\mathrm{RT}<30 \mathrm{~Gy}$ & RT 30-45 Gy & RT 45-65 Gy \\
\hline Digit span forward & $\begin{array}{c}5.1 \pm 0.4 \\
p<0.05 ; p<0.01\end{array}$ & $\begin{array}{l}3.3 \pm 1.4 \\
p<0.05\end{array}$ & $2.7 \pm 0.8$ \\
\hline Digit span backward & $\begin{array}{c}4.3 \pm 0.7 \\
p<0.01 ; p<0.01\end{array}$ & $\begin{array}{l}2.0 \pm 2.2 \\
p<0.01\end{array}$ & $1.6 \pm 0.3$ \\
\hline BEHAVE-AD & $\begin{array}{c}4.8 \pm 1.4 \\
p<0.01 ; p<0.01\end{array}$ & $\begin{array}{l}8.7 \pm 3.8 \\
p<0.01\end{array}$ & $10.6 \pm 4.5$ \\
\hline AES-S & $\begin{array}{c}12.6 \pm 1.4 \\
p<0.01 ; p<0.01\end{array}$ & $\begin{array}{c}27.5 \pm 1.4 \\
p<0.01\end{array}$ & $39.8 \pm 3.4$ \\
\hline AES-C & $\begin{array}{c}17.2 \pm 1.4 \\
p<0.01 ; p<0.01\end{array}$ & $\begin{array}{c}30.8 \pm 1.4 \\
p<0.01\end{array}$ & $45.2 \pm 2.2$ \\
\hline Tinetti Equilibrium & $\begin{array}{c}12.0 \pm 0.1 \\
p<0.05 ; p<0.01\end{array}$ & $\begin{array}{c}9.13 \pm 0.4 \\
p<0.01\end{array}$ & $6.1 \pm 0.8$ \\
\hline Tinetti Gait & $\begin{array}{c}9.2 \pm 1.1 \\
p<0.05 ; p<0.01\end{array}$ & $\begin{array}{l}7.5 \pm 1.2 \\
p<0.01\end{array}$ & $2.2 \pm 1.1$ \\
\hline Tinetti Total Score & $\begin{array}{c}21.2 \pm 1.2 \\
p<0.05 ; p<0.01\end{array}$ & $\begin{array}{c}16.38 \pm 1.3 \\
p<0.01\end{array}$ & $8.4 \pm 1.2$ \\
\hline
\end{tabular}

All the patients who received oral chemotherapy plus RT, 18 patients in the 30-45 Gy subgroup, and 44 in the 45-65 Gy subgroup more rapidly manifested gait disorders and more severe and rapid cognitive deterioration, associated with a loss of awareness, and were bed-ridden at the end of the follow-up.

\subsection{Observations}

In our patients, we observed a cognitive and behavior decline, exposed to significant RT doses, 30-65 Gy, similar to what was typically observed in SVAD (dysexecutive functions, apathy, and gait alterations), but with a more rapid onset and with an overwhelming effect. The observed neuropsychological deterioration was comparable with the observed increase in white matter hyper-intensities on the T2-weighted images, markedly on the periventricular regions, in the internal capsule, the paraventricular frontal and basal ganglia areas, and much more evident in the patients exposed to 45-65 Gy. The interruption of the frontal subcortical loops, which is continuously seen in SVD brain disease and SVAD, occurs in RT; the time of onset and speediness of occurrence is higher than the usual progression of SVAD, as it has been described in many different works and reviews $[12,17,43]$. It seems quite interesting that the same neural networks (frontal-basal ganglia-subthalamus and parietal cortex) participate in walking and gait control as well $[9,12,14,20]$.

\section{Radiotherapy Effects}

Our results were concordant with the RT-delayed onset consequences in the brain of the patients who undergo it.

A few autopsy studies demonstrated that RT drove to diffuse myelin destruction, with the relative preservation of axons and large blood vessels [43]. The volume of brain receiving $\geq 12$ Gy has been shown to correlate with the incidence of radiation necrosis and asymptomatic radiologic changes, and the presence of comorbid vascular risk factors (e.g., diabetes) might potentiate it [44-46].

Three different hypotheses were claimed out [47] to explain radiotherapy harm in brain tissue:

1. Possible pro-oxidative stress and inflammatory induction by radiotherapy;

2. Possible effect on matrix metalloproteinases and extracellular matrix in the brain;

3. Possible effect on brain angiogenesis. 
Another theory of radiotherapy-induced brain damage should be mentioned, which is well known, sufficiently proven, even if not universally accepted. The human brain observational studies together with many animal experiments are entirely in agreement with the fact that there is a constant area of sufferance in the brain which undergoes RT, the so-called subventricular zone (SVZ) [48-56]. The SVZ area is fundamental in new-born and young animals, but has a specific role in the adult brain too; the SZV is the area where neurogenesis occurs in the adult mammalian brains, associated with some parts of the lateral walls of the ventricles, the dentate gyrus of the hippocampus and the olfactory bulb [57]. Human SVZ could promote glial precursors, towards the basal forebrain, throughout the white matter of the human brain [57], which seems to contribute to the postnatal myelination of the white matter of the frontal lobes [56,57], and RT could somehow alter the neurogenic microenvironment of the white matter of the frontal regions $[55,56]$. In this region, there is a proven activation of the local microglia, with a constant increase in IL-6, which seems to block the neuronal differentiation and decrease oligodendroglial proliferation [55-62]. The most vulnerable regions for cognitive radiation damages were outlined in different studies, and included the corpus callosum, left frontal white matter, right temporal lobe, bilateral hippocampi, subventricular zone, and cerebellum [63].

Oxidative stress and inflammation are the suspected crucial pathways that lead to radiation-induced brain injury [64-69]. A marked elevation of COX-1/-2 activity and prostaglandin E2 (PGE2) synthesis occurs in the brain following ionizing radiation; this evidence is in favor of a general CNS inflammation. In fact, in the CNS after RT, there is an up-regulation of different pro-inflammatory mediators, including tumor necrosis factor- $\alpha$ (TNF- $\alpha$ ), IL-1 $\beta$, IL-6, inducible nitric oxide synthase (iNOS), intercellular adhesion molecule-1 (ICAM-1), and matrix metalloproteinase- 9 (MMP-9) [70,71], among others. Enhanced adhesion molecules, such as ICAM-1, vascular cell adhesion molecule-1 (VCAM-1), and E-selectin, were observed in irradiated brains $[64,65,68,69]$. The rapid induction of the gene expressions of the pro-inflammatory cytokines, such as TNF- $\alpha$ and IL- $1 \beta$, in response to radiation, was identified [64,68]. Moreover, a significant and marked up-regulation of mRNA and protein expression of pro-inflammatory mediators, including TNF- $\alpha$, IL- $1 \beta$, and monocyte chemoattractant protein-1 (MCP-1), was observed in the hippocampal and cortical regions isolated from irradiated brains. Interestingly, cytokine expression was regionally specific since TNF- $\alpha$ levels were significantly elevated in the cortex compared to the hippocampus, and IL-1 $\beta$ levels were elevated in the hippocampus compared to cortical samples. A series of electrophoretic mobility shift assays (EMSAs) also demonstrated that the whole-brain radiation significantly increased pro-oxidative and pro-inflammatory transcription factors, including AP-1, NF-kB, and CREB [72,73].

In vitro and in vivo studies showed that whole-brain radiation strongly activates the microglia in the general pro-inflammatory response [73,74]. Therefore, oxidative stress-mediated inflammation is one of the significant consequences of whole-brain radiation and plays a pivotal role in subsequent radiation-induced tissue injury to a healthy brain.

Radiotherapy disrupts the blood-brain barrier (BBB), altering the functional structure of the brain's microvasculature and increasing its permeability [75-81]. The most intriguing aspect is that RT seems to damage healthy capillaries rather than those inside the tumor [78]. This was even more true in response to interstitial brachytherapy $[79,80]$.

There is a very well accepted and proven mechanism by which BBB disruption occurs after RT. However, it seems possible that RT has specific targets, such as the extracellular matrix (ECM) proteins and proteoglycans, including collagens, laminin, fibronectin, and tenascin [82], which are the major constituents of the BBB $[82,83]$. The most sensitive family of the ECM subgroups to RT are the matrix metalloproteinases (MMPs), a large family of ECM-degrading enzymes [84-86]. MMPs are partitioned into gelatinases (MMP-2 and -9), collagenases (MMP-1, -8, -13, and -18), stromelysins (MMP-3, -10, and -11), matrilysins (MMP-7 and -26), metalloelastase (MMP-12), and membrane-type (MT) MMPs (MMP-14, -15, -16, -17, -24, and -25) [84,87]. In this case, damage to MMP-2 and MMP-9 can damage collagen type IV, which is essential for maintaining BBB integrity [85]. Moreover, the MMP activity is regulated by endogenous tissue inhibitors of metalloproteinases (TIMPs) $[84,85,87]$. For example, 
TIMP-1 inhibits MMP9 activity by forming a specific complex with MMP-9, whereas TIMP-2 bounds MMP-2 [88-90]. Consequently, a favorable balance of MMPs/TIMPs system maintains the BBB integrity $[85,91]$. This imbalance has been documented in different tissues, among them the brain, lung, thorax [92,93], prostate and rectal mucosa [94], with the overexpression of MMP-2 and MMP-9, but without the concomitant activation of TIMP, i.e., TIMP-2, [95], therefore making possible only the proteolytic activity. This activity was documented in specific brain cell types, i.e., astrocytes, endothelium, and oligodendrocytes [96,97], where RT induces an overwhelming promotion of MMP and dysregulates TIMP, exerting a generalized proteolytic effect [47].

One potential experimental approach is to administer a series of pharmacological agents that selectively inhibit MMPs by different mechanisms of action, including minocycline, simvastatin, AG3340, DPC-A37668, GM6001, PD166793, and Ro-31-9790 [98-100], anti-inflammatory [101], anti-oxidants [102] to animal models of whole-brain radiation therapy. However, results are not definite at all [47].

\section{Radiotherapy Damage and Small Vessel Disease: Common Points}

Between several different hypotheses of late radiation-induced brain injury, the vascular hypothesis could be a consequence of white matter necrosis.

In the RT brain, many vascular changes were observed: vessel wall thickening, vessel dilation, endothelial cell nuclear enlargement, capillary rarefaction, and general tissue hypoxia [12]. As reported above, besides the vascular hypothesis, oligodendrocytes, astrocytes, and microglia's pro-inflammatory responses have been described $[43,103]$. The consequence is the diffuse sufferance of the white matter, comparable to that seen in subcortical vascular dementia [104]. Apart from the apparent necrotic region, induced by RT damage, the immunohistochemical analysis of the brains which undergo to RT found a substantial decrease in myelin-basic protein-positive fibers in radiated areas, with a moderate lessening of the neurofilament-positive fibers, which are variously dispersed in the radiated territories. Simultaneously, there is an evident increase in the gliosis process, which is testified by an increase in the quote of glial fibrillary acidic protein-positive fibers. These findings are similar to those in clinically accelerated brain aging in diffuse subcortical ischemia [12,43,47,103].

Cerebral small vessel disease (SVD) primarily distresses the small perforating arteries, supplying the deep brain structures and the leptomeningeal space $[104,105]$. The small-vessel disease is significantly related to the loss of the arterial elasticity, with a significant lessening of arterial compliance, low-level functioning of the autonomic nervous system, with altered baroreflex activity [106-111]. Arteriolosclerosis extents the hypo-perfusion in the profound territories [112,113], irrigated by penetrating arteries [114-117]; its consequence is potentiated by the loss of the cholinergic integrity [118] and promoted by itself a functional disconnection from the tubero-mamillary tracts [119-121].

Moreover, in SVD, the perivascular spaces (PVS) were damaged [122]. They act as a brain lymphatic system [123], and their modifications induce a decrease in catabolic drainage, an amassing of catabolites and toxic substances, together with a pronounced neural starvation [123-125] and the interference of the blood-brain barrier integrity [126-130].

Thus, SVD could be simplistically summarized by two main processes, progressive hypoperfusion, triggering the incomplete ischemia of the deep white matter [131-134] associated with an inflammation of the white matter. These two biological events induce histological modifications of the white matter, very similar to those observed in the post-RT brain: a diffuse rarefaction of myelin sheaths, followed by an axonal disruption and severe astrocyte gliosis [117]. We have all the data concerning RT brains, but in SVD, something more complex occurs too: there is a complex disruption of the glymphatic system, associated (or caused) by the occlusion of the deep periventricular-draining veins [135], together with a disruption of the BBB [131-133].

As far as the inflammatory events proceed, either in post-RT or SVD, we can find crucial microglial activation, also promoting the apoptosis processes. There is an elevation of caspase 3 RNA, and of matrix- metalloprotease 2 (MMP-2) expression [136,137], with a marked astrocytosis at the first part of 
the process, and then with their death (the following part has not been described in the post-RT brain, probably due to the long-lasting observation period, typical of SVD and not of post-RT) [138-142]. In SVD, the astrocytic death includes a severe alteration of the precarious neurovascular coupling system, leading to its destruction [143].

The effects of the inflammation in the SVD act indirectly on the endothelium $[143,144]$. It is widely demonstrated that, due to an altered response to endothelium-derived nitric oxide-vasodilators $[145,146]$, prostacyclin [147] and endothelium-derived hyperpolarizing factors (EDHF) [148], there is an accelerated mitochondrial senescence of the endothelium walls [144]. The reduction of the mitochondrial strength leads to an essential lessening of NO production, with an unrestrained production of O2 [149,150]. The pathological reduction of NO is related to the downregulation of the Rho-associated protein kinase (ROCK) [151]. ROCK interacts with ezrin, radixin, and moesin, also known as the ERM proteins, that are fundamental for membrane integrity and the leukocyte adhesion molecules' coordination, with the significant consequence for inflammation response, for endothelium integrity, and brain barrier integrity [152-156], also helped by the regulation of VE-cadherins [157-159].

The strong aftereffects of mitochondrial senescence, oxidative damage on endothelium, and brain barrier induce a cascade of potentiating events on inflammation [159]. All the principal mechanisms of inflammation, apoptosis, necroptosis, Wallerian degeneration, demyelination, astrocytosis, and microglial activation have been documented in SVD [160-162]. The loss of plasma membrane integrity is involved in a peculiar phenomenon, observed in SVD, called necroptosis. Necroptosis is different from apoptosis because it is programmed cell death, not involving caspase but the loss of plasma membrane integrity, through the receptor-interacting serine/threonine-protein kinase (RIPK-1) and the mixed lineage kinase domain-like (MLKL) [163-165]. Wallerian degeneration also occurs in SVD, which is shared with post-RT consequences [117].

Inflammation for SVD has been evoked as a priming effect, even at a distance, in the so-called microbiome-gut-brain axis [166-171]. Age is the main dominant promoting factor that leads to a series of altered responses to inflammation and oxidative process in the brain; SVD is a potentiated aging process $[117,143]$. Recently, neurodegeneration-inflammation-aging has been defined as "inflammaging" [172-176]. The loss of oxidative repair process in SVD leads to the constant activation of the glial cells [176], which endorses telomere shortening, frequently observed in many neurodegenerative conditions [177].

Oxidative stress is the critical mediator of the cascade of events derived from chronic or global hypoxia in different animal models [178]. The reduction of NO bioavailability leads to lessened anti-inflammatory properties, which promotes other oxidant molecules, accentuating vascular dysfunction, damage to proteins and DNA, and the loss of modulation of Rho-kinase activity [179], with the consequent decrease in vascular tone control [180-182], therefore disabling the neurovascular coupling [183-185].

Either in animal models, in SVD or in post-RT brain damage, ROS-mediated ischemic injuries have been described.

Nox2-NADPH oxidase is a crucial mediator of ischemic brain injury leading to BBB disruption and the dysfunction of larger pial arteries; a primary confirmation of this aspect is that Nox2-deficient mice have less brain injury after focal ischemia [186].

Potential treatment strategies for SVD and post-radiotherapy damage might include those that target antioxidant effects for the endothelium of small cerebral vessels [187] and the BBB [188,189]. Given NO bioavailability is impaired in SVD, NO donors could be useful in releasing the functioning endothelium of small vessel disease, limited by their susceptibility to tolerance development [187,190,191]. The apparent strategy, like the administration of potent antioxidants such as Vitamins C and E, has shown to be beneficial for vascular function in several experimental and small clinical trials [192-194]. Disappointingly, the results of large clinical trials of antioxidant supplementation have largely failed to show any benefit $[195,196]$. The ROS scavenger tempol is cell-permeable and has been used in experimental studies [197,198], as well as edavarone (O2-scavenger) [199]. Problems derived from 
NADPH oxidase activity, in particular its primary contributor, Nox2. Nevertheless, this isoform is also expressed in phagocytic immune cells; thus, it can be argued that prolonged selective therapies could help to prevent SVD, but invariably lead to an immunosuppression condition, as well as to many other side effects derived by different other Nox oxidases [200-210].

\section{Conclusions}

From what was reported above, and from our data, it seems quite evident that many mechanisms can be evoked to explain the mechanism through which radiotherapy acts, but what remains quite evident is that the most critical damage target is the small vessel arbor. Together with the small vessels, the other main targets of RT, outside the tumor mass are the BBB and the white matter areas. The active mechanisms that RT drives are similar to those observed in SVD [211,212]. What impresses on the active site of RT brain damage is the white matter areas, particularly the internal capsule, basal ganglia, caudate, hippocampus, and subventricular zone. In all the cases, radiation damage inside the brain mainly focuses on the cortical-subcortical frontal loops, which integrate and process the flow of information from the cortical areas, where executive functions are "elaborated" and prepared, towards the thalamus, subthalamus, and cerebellum, where they were continuously refined and executed $[213,214]$. Cerebral atrophy with diffuse demyelination and spongiform changes in the white matter is seen pathologically [215]. This typical disposition clarifies the cognitive and behavioral subcortical frontal and white matter alterations observed in different patients.

These data are entirely per the results presented from our study reported herein. The main difference between pure SVD and post-RT damage is the speediness of damage accumulation, typical of RT damage, and it is strongly related to the total amount of given radiation. Putative mechanisms that can be taken into account are oxidative stress and neuro-inflammation, strongly associated with the alteration of NMDA receptor subunit composition [211]. A strong preponderance of evidence supports the hypothesis that late radiation injury in the brain is driven by acute and chronic oxidative stress and inflammatory response, generating ROS, which leads to a cascade of events, the primary of which is the damage of DNA, cell membrane bilayers, and the activation of early response transcription factors and signal transduction pathways [212].

Even in a small number of clinical trials, particularly at the time of enrollment, more precise biochemical definition strategies must refer to these therapeutic choices as future options, which will need more robust and affordable, more extensive studies.

Author Contributions: R.M. collected the data and conceptualized and wrote the manuscript: P.C. revised it and prepared and checked references. All authors have read and agreed to the published version of the manuscript.

Funding: This research received no external funding.

Acknowledgments: The Authors thank Andrew Cunningham, for his assistance in editing the text.

Conflicts of Interest: The authors declare no conflict of interest.

\section{References}

1. Kitson, S.L.; Cuccurullo, V.; Moody, T.S.; Mansi, L. Radionuclide antibody-conjugates, a targeted therapy towards cancer. Curr. Radiopharm. 2013, 6, 57-71. [CrossRef]

2. Cuccurullo, V.; Di Stasio, G.D.; Cascini, G.L.; Gatta, G.; Bianco, C. The Molecular Effects of Ionizing Radiations on Brain Cells: Radiation Necrosis vs. Tumor Recurrence. Diagnostics 2019, 9, 127. [CrossRef]

3. Tofilon, P.J.; Fike, J.R. The radioresponse of the central nervous system: A dynamic process. Radiat. Res. 2000, 153, 357-370. [CrossRef]

4. Kim, J.H.; Brown, S.L.; Jenrow, K.A.; Ryu, S. Mechanisms of radiation-induced brain toxicity and implications for future clinical trials. J. Neurooncol. 2008, 87, 279-286. [CrossRef]

5. Ramanan, S.; Zhao, W.; Riddle, D.R.; Robbins, M.E. Role of PPARs in Radiation-Induced Brain Injury. PPAR Res. 2009, 2010, 234975. [CrossRef] 
6. Schultheiss, T.E.; Stephens, L.C. Invited review: Permanent radiation myelopathy. Br. J. Radiol. 1992, 65, 737-753. [CrossRef]

7. Imperato, J.P.; Paleologos, N.A.; Vick, N.A. Effects of treatment on long-term survivors with malignant astrocytomas. Ann. Neurol. 1990, 28, 818-822. [CrossRef]

8. Barker, F.G., 2rd; Butler, W.E.; Lyons, S.; Cascio, E.; Ogilvy, C.S.; Loeffler, J.S.; Chapman, P.H. Dose-volume prediction of radiation-related complications after proton beam radio-surgery for cerebral arteriovenous malformations. J. Neurosurg. 2003, 99, 254-263. [CrossRef]

9. Klein, M.; Heimans, J.; Aaronson, N.; Van Der Ploeg, H.; Grit, J.; Muller, M.; Postma, T.; Mooij, J.; Boerman, R.; Beute, G.; et al. Effect of radiotherapy and other treatment-related factors on mid-term to long-term cognitive sequelae in low-grade gliomas: A comparative study. Lancet 2002, 360, 1361-1368. [CrossRef]

10. Dropcho, E.J. Neurologic Complications of Cancer Therapy; American Academy of Neurology: Minneapolis, MN, USA, CD-MEETING COLLECTION; 2003; pp. 1-32.

11. Moretti, R.; Torre, P.; Antonello, R.M.; Cattaruzza, T.; Cazzato, G.; Bava, A.; Ukmar, M.; Korczyn, A.D. Neuropsychological evaluation of late-onset post-radiotherapy encephalopathy: A comparison with vascular dementia. J. Neurol. Sci. 2005, 229, 195-200. [CrossRef]

12. Moretti, R.; Caruso, P.; Signori, R.; Tonon, A.; Del Ben, M.; Gazzin, S. Subcortical vascular damages for post-radiation brain radiotherapy. Int. J. Dev. Res. 2016, 10, 9722-9730.

13. Kasenda, B.; Illerhaus, G. CNS border posts against rituximab? Lancet Oncol. 2019, 20, 169-170. [CrossRef]

14. Paleologos, N.A. Neurologic Complications of Radiation Therapy and Chemotherapy; American Academy of Neurology: Minneapolis, MN, USA, CD-MEETING COLLECTION, 5FC. 003; 2000; pp. 126-151.

15. Monje, M.; Dietrich, J. Cognitive side effects of cancer therapy demonstrate a functional role for adult neurogenesis. Behav. Brain Res. 2012, 227, 376-379. [CrossRef]

16. Grunert, M.; Kassubek, R.; Danz, B.; Klemenz, B.; Hasslacher, S.; Stroh, S.; Schneele, L.; Langhans, J.; Ströbele, S.; Barry, S.E.; et al. Radiation and Brain Tumors: An Overview. Crit. Rev. Oncog. 2018, 23, 119-138. [CrossRef]

17. Karim, A.B.M.F.; Afra, D.; Cornu, P.; Bleehan, N.; Schraub, S.; De Witte, O.; Darcel, F.; Stenning, S.; Pierart, M.; Van Glabbeke, M. Randomized trial on the efficacy of radiotherapy for cerebral low-grade glioma in the adult: European Organization for Research and treatment of cancer study 22845 with the Medical Research Council Study Bro4: An interim analysis. Int. J. Radiat. Oncol. Biol. Phys. 2001, 52, 316-324. [CrossRef]

18. Jenkinson, M.D.; Javadpour, M.; Haylock, B.J.; Young, B.; Gillard, H.; Vinten, J.; Bulbeck, H.; Das, K.; Farrell, M.; Looby, S.; et al. The ROAM/EORTC-1308 trial: Radiation versus Observation following surgical resection of Atypical Meningioma: Study protocol for an international randomised controlled trial. Trials 2015, 14, 519. [CrossRef]

19. Velikova, G.; Coens, C.; Efficace, F.; Greimel, E.; Groenvold, M.; Johnson, C.; Singer, S.; Van De Poll-Franse, L.; Young, T.; Bottomley, A. Health-related quality of life in EORTC clinical trials-30 years of progress from methodological developments to making a real impact on oncology practice. EJC Suppl. 2012, 10, 141-149. [CrossRef]

20. Bitterlich, C.; Vordermark, D. Analysis of health-related quality of life in patients with brain tumors prior and subsequent to radiotherapy. Oncol. Lett. 2017, 14, 1841-1846. [CrossRef]

21. Welzel, G.; Fleckenstein, K.; Schaefer, J.; Hermann, B.; Kraus-Tiefenbacher, U.; Mai, S.K.; Wenz, F. Memory function before and after whole brain radiotherapy in patients with and without brain metastases. Int. J. Radiat. Oncol. Biol. Phys. 2008, 72, 1311-1318. [CrossRef]

22. Douw, L.; Klein, M.; Fagel, S.S.; van den Heuvel, J.; Taphoorn, M.J.; Aaronson, N.K.; Postma, T.J.; Vandertop, W.P.; Mooij, J.J.; Boerman, R.H.; et al. Cognitive and radiological effects of radiotherapy in patients with low-grade glioma: Long-term followup. Lancet Neurol. 2009, 8, 810-818. [CrossRef]

23. Warrington, J.P.; Csiszar, A.; Mitschelen, M.; Lee, Y.W.; Sonntag, W.E. Whole brain radiation-induced impairments in learning and memory are time-sensitive and reversible by systemic hypoxia. PLoS ONE 2012, 7, e30444. [CrossRef] [PubMed]

24. Román, G.C.; Tatemichi, T.K.; Erkinjuntti, T.; Cummings, J.L.; Masdeu, J.C.; Garcia, J.H.; Amaducci, L.; Orgogozo, J.M.; Brun, A.; Hofman, A.; et al. Vascular dementia: Diagnostic criteria for research studies. Report of the NINDS-AIREN international workshop. Neurology 1993, 43, 250-260. [CrossRef] [PubMed]

25. Erkinjuntti, T.; Ketonen, L.; Sulkava, R.; Vuorialho, M.; Palo, J. CT in the differential diagnosis between Alzheimer's disease and vascular dementia. Acta Neurol. Scand. 1987, 75, 262-270. [CrossRef] [PubMed] 
26. Marshall, G.A.; Shchelchkov, E.; Kaufer, D.I.; Ivanco, L.S.; Bohnen, N.I. White matter hyperintensities and cortical acetylcholinesterase activity in parkinsonian dementia. Acta Neurol. Scand. 2006, 113, 87-91. [CrossRef]

27. Fazekas, F.; Chawluk, J.B.; Alavi, A.; Hurtig, H.I.; Zimmermann, R.A. MR signal abnormalities at $1.5 \mathrm{~T}$ in Alzheimer's dementia and normal aging. Am. J. Roentgenol. 1987, 149, 351-356. [CrossRef]

28. Cleutjens, F.A.H.M.; Ponds, R.W.H.M.; Spruit, M.A.; Burgmans, S.; Jacobs, H.I.; Gronenschild, E.H.B.M.; Staals, J.; Franssen, F.M.E.; Dijkstra, J.B.; Vanfleteren, L.E.G.W.; et al. The relationship between cerebral small vessel disease, hippocampal volume and cognitive functioning in patients with COPD: An MRI study. Front. Aging Neurosci. 2017, 9, 88. [CrossRef]

29. Blennow, K.; Wallin, A.; Uhlemann, C.; Gottfries, C.G. White-matter lesions on CT in Alzheimer patients: Relation to clinical symptomatology and vascular factors. Acta Neurol. Scand. 1991, 83, 187-193. [CrossRef]

30. Wallin, A.; Blennow, K. Pathogenetic basis of vascular dementia. Alzheimer Dis. Assoc. Disord. 1991, 5, 91-102. [CrossRef]

31. Scheltens, P.; Barkhof, F.; Leys, D.; Pruvo, J.; Nauta, J.; Vermersch, P.; Steinling, M.; Valk, J. A semiquantative rating scale for the assessment of signal hyperintensities on magnetic resonance imaging. J. Neurol. Sci. 1993, 114, 7-12. [CrossRef]

32. Kim, G.H.; Lee, J.H.; Seo, S.W.; Ye, B.S.; Cho, H.; Kim, H.J.; Noh, Y.; Yoon, C.W.; Chin, J.H.; Oh, S.J.; et al. Seoul criteria for PIB(-) subcortical vascular dementia based on clinical and MRI variables. Neurology 2014, 82, 1529-1535. [CrossRef]

33. Vardy, J.; Wefel, J.S.; Ahles, T.; Tannock, I.F.; Schagen, S.B. Cancer and cancer therapy related cogntive dysfunction: An international perspective from the Venice cognitive workshop. Ann. Oncol. 2008, 19, 623-629. [CrossRef] [PubMed]

34. Wefel, J.S.; Vardy, J.; Ahles, T.; Schagen, S.B. International Cognition and Cancer TAsk force recommendations to harmonise studies of cognitive function in patients with cancer. Lancet Oncol. 2011, 12, 703-708. [CrossRef]

35. Folstein, M.; Folstein, S.; McHugh, P. Mini-Mental state. A practical method for grading the cognitive state of patients for the clinician. J. Psychiatr. Res. 1975, 12, 189-198. [CrossRef]

36. Wechsler, D. A standardised memory scale for clinical use. J. Psychol. 1945, 19, 87-97. [CrossRef]

37. Wechsler, D. Wechsler Adult Intelligence Scale-R.-Manual; Psychological Corp: New York, NY, USA, 1981.

38. Paradis, M.; Canzanella, M. Test Per L'afasia in Un Bilingue: Versione Italiana; Erlbaum: Hillsdale, NJ, USA, 1990.

39. Marin, R.S.; Biedrzycki, R.C.; Firinciogiullari, S. Reliability and validity of the apathy evaluation scale. Psychiatry Res. 1991, 38, 143-162. [CrossRef]

40. Reisberg, B.; Borenstein, J.; Salob, S.P.; Ferris, S.H.; Franssen, E.; Georgotas, A. Behavioural symptoms in Alzheimer's disease: Phenomenology and treatment. J. Clin. Psychiatry 1987, 48, 9-15. [PubMed]

41. Tinetti, M.E. Performance-oriented assessment of mobility problems in elderly patients. J. Am. Geriatr. Soc. 1986, 34, 119-126. [CrossRef]

42. Briggs, G.G.; Nebes, R.D. Patterns of hand preference in a student population. Cortex 1975, 11, $230-238$. [CrossRef]

43. De Angelis, L.M.; Delatore, J.Y.; Posner, J.B. Radiation-induced dementia in patients cured of brain metastases. Neurology 1989, 39, 789-796. [CrossRef]

44. Lee, A.W.; Kwong, D.L.W.; Leung, S.F.; Tung, S.Y.; Sze, W.M.; Sham, J.S.T.; Teo, P.M.L.; Leung, T.W.; Wu, P.M.; Chappell, R.; et al. Factors affecting risk of symptomatic temporal lobe necrosis: Significance of fractional dose and treatment time. Int. J. Radiat. Oncol. Biol. Phys. 2002, 53, 75-85. [CrossRef]

45. Wong, C.S.; Van der Kogel, A.J. Mechanisms of radiation injury to the central nervous system: Implications for neuroprotection. Mol. Interv. 2004, 4, 273-284. [CrossRef] [PubMed]

46. Greene-Schloesser, D.; Robbins, M.E.; Peiffer, A.M.; Shaw, E.G.; Wheeler, K.T.; Chan, M.D. Radiation-induced brain injury: A review. Front. Oncol. 2012, 2. [CrossRef] [PubMed]

47. Lee, Y.W.; Cho, H.J.; Lee, W.E.; Sonntag, W.E. Whole Brain Radiation-Induced Cognitive Impairment: Pathophysiological Mechanisms and Therapeutic Targets. Biomol. Ther. 2012, 20, 357-370. [CrossRef]

48. Geha, S.; Pallud, J.; Junier, M.P.; Devaux, B.; Leonard, N.; Chassoux, F.; Chneiweiss, H.; Daumas-Duport, C.; Varlet, P. NG2+/Olig2+ cells are the major cycle-related cell population of the adult human normal brain. Brain Pathol. 2010, 20, 399-411. [CrossRef] [PubMed]

49. Eriksson, P.S.; Perfilieva, E.; Björk-Eriksson, T.; Alborn, A.-M.; Nordborg, C.; Peterson, D.A.; Gage, F.H. Neurogenesis in the adult human hippocampus. Nat. Med. 1998, 4, 1313-1317. [CrossRef] [PubMed] 
50. Van Praag, H.; Christie, B.R.; Sejnowski, T.J.; Gage, F.H. Running enhances neurogenesis, learning, and long-term potentiation in mice. Proc. Natl. Acad. Sci. USA 1999, 96, 13427-13431. [CrossRef]

51. Kempermann, G.; Kuhn, H.G.; Gage, F.H. More hippocampal neurons in adult mice living in an enriched environment. Nature 1997, 386, 493-495. [CrossRef]

52. Chang, A.; Nishiyama, A.; Peterson, J.; Prineas, J.; Trapp, B.D. NG2-positive oligodendrocyte progenitor cells in adult human brain and multiple sclerosis lesions. J. Neurosci. 2000, 20, 6404-6412. [CrossRef]

53. Dawson, M.R.; Polito, A.; Levine, J.M.; Reynolds, R. NG2-expressing glial progenitor cells: An abundant and widespread population of cycling cells in the adult rat CNS. Mol. Cell Neurosci. 2003, 24, 476-488. [CrossRef]

54. Zhao, C.; Deng, W.; Gage, F.H. Mechanisms and functional implications of adult neurogenesis. Cell 2008, 132, 645-660. [CrossRef]

55. Monje, M.L.; Mizumatsu, S.; Fike, J.R.; Palmer, T.D. Irradiation induces neural precursor-cell dysfunction. Nat. Med. 2002, 8, 955-962. [CrossRef]

56. Kangas, M.; Tate, R.L.; Williams, J.R.; Smee, R.I. The effects of radiotherapy on psychosocial and cognitive functioning in adults with a primary brain tumor: A prospective evaluation. Neuro Oncol. 2012, 14, 1485-1502. [CrossRef] [PubMed]

57. Quinones-Hinojosa, A.; Caichana, K. The human subventricualr zone: A source of new cells and a potential source of brain tumours. Exp. Neurol. 2007, 205, 313-324. [CrossRef] [PubMed]

58. Welzel, G.; Fleckenstein, K.; Mai, S.K.; Hermann, B.; Kraus-Tiefenbacher, U.; Wenz, F. Acute neurocognitive impairment during cranial radiation therapy in patients with intracranial tumors. Strahlenther. Onkol. 2008, 184, 647-654. [CrossRef] [PubMed]

59. Johannesen, T.B.; Lien, H.H.; Hole, K.H.; Lote, K. Radiological and clinical assessment of long-term brain tumour survivors after radiotherapy. Radiother. Oncol. 2003, 69, 169-176. [CrossRef]

60. Brown, W.R.; Blair, R.M.; Moody, D.M.; Thore, C.R.; Ahmed, S.; Robbins, M.E.; Wheeler, K.T. Capillary loss precedes the cognitive impairment induced by fractionated whole-brain irradiation: A potential rat model of vascular dementia. J. Neurol. Sci. 2007, 257, 67-71. [CrossRef]

61. Gondi, V.; Tomé, W.A.; Mehta, M. Why Avoid the Hippocampus? A Comprehensive Review. Radiother. Oncol. 2010, 97, 370-376. [CrossRef]

62. Warrington, J.P.; Ashpole, N.; Csiszar, A.; Lee, Y.W.; Ungvari, Z.; Sonntag, W.E. Whole Brain Radiation-Induced Vascular Cognitive Impairment: Mechanisms and Implications. J. Vasc. Res. 2013, 50, 445-457. [CrossRef]

63. Peiffer, A.M.; Leyrer, C.M.; Greene-Schloesser, D.M.; Shing, E.; Kearns, W.T.; Hinson, W.H.; Tatter, S.B.; Ip, E.H.; Rapp, S.R.; Robbins, M.E.; et al. Neuroanatomical target theory as a predictive model for radiation-induced cognitive decline. Neurology 2013, 80,747-775. [CrossRef]

64. Hong, J.-H.; Chiang, C.-S.; Campbell, I.L.; Sun, J.-R.; Withers, H.; McBride, W.H. Induction of acute phase gene expression by brain irradiation. Int. J. Radiat. Oncol. Biol. Phys. 1995, 33, 619-626. [CrossRef]

65. Olschowka, J.A.; Kyrkanides, S.; Harvey, B.K.; O’Banion, M.K.; Williams, J.; Rubin, P.; Hansen, J.T. ICAM-1 induction in the mouse CNS following irradiation. Brain Behav. Immun. 1997, 11, 273-285. [CrossRef] [PubMed]

66. Chiang, C.S.; Hong, J.H.; Stalder, A.; Sun, J.R.; Withers, H.R.; McBride, W.H. Delayed molecular responses to brain irradiation. Int. J. Radiat. Biol. 1997, 72, 45-53. [CrossRef] [PubMed]

67. Kim, S.H.; Lim, D.J.; Chung, Y.G.; Cho, T.H.; Lim, S.J.; Kim, W.J.; Suh, J.K. Expression of TNF-alpha and TGF-beta 1 in the rat brain after a single high-dose irradiation. J. Korean Med. Sci. 2002, 17, 242-248. [CrossRef] [PubMed]

68. Gaber, M.W.; Sabek, O.M.; Fukatsu, K.; Wilcox, H.G.; Kiani, M.F.; Merchant, T.E. Differences in ICAM-1 and TNF-alpha expression between large single fraction and fractionated irradiation in mouse brain. Int. J. Radiat. Biol. 2003, 79, 359-366. [CrossRef] [PubMed]

69. Baluna, R.G.; Eng, T.Y.; Thomas, C.R. Adhesion molecules in radiotherapy. Radiat. Res. 2006, 166, 819-831. [CrossRef] [PubMed]

70. Kyrkanides, S.; Moore, A.H.; Olschowka, J.A.; Daeschner, J.C.; Williams, J.P.; Hansen, J.T.; Kerry O’Banion, M. Cyclooxygenase-2 modulates brain infl ammation-related gene expression in central nervous system radiation injury. Brain Res. Mol. Brain Res. 2002, 104, 159-169. [CrossRef]

71. Moore, A.H.; Olschowka, J.A.; Williams, J.P.; Okunieff, P.; O’Banion, M.K. Regulation of prostaglandin E2 synthesis after brain irradiation. Int. J. Radiat. Oncol. Biol. Phys. 2005, 62, 267-272. [CrossRef] 
72. Raju, U.; Gumin, G.J.; Tofi Lon, P.J. Radiation-induced transcription factor activation in the rat cerebral cortex. Int. J. Radiat. Biol. 2000, 76, 1045-1053. [CrossRef]

73. Lee, W.H.; Sonntag, W.E.; Mitschelen, M.; Yan, H.; Lee, Y.W. Irradiation induces regionally specific alterations in proinflammatory environments in rat brain. Int. J. Radiat. Biol. 2010, 86, 132-144. [CrossRef]

74. Conner, K.R.; Forbes, M.E.; Lee, W.H.; Lee, Y.W.; Riddle, D.R. AT1 receptor antagonism does not influence early radiation induced changes in microglial activation or neurogenesis in the normal rat brain. Radiat. Res. 2011, 176, 71-83. [CrossRef]

75. Diserbo, M.; Agin, A.; Lamproglou, I.; Mauris, J.; Staali, F.; Multon, E.; Amourette, C. Blood-brain barrier permeability after gamma whole-body irradiation: An in vivo microdialysis study. Can. J. Physiol. Pharmacol. 2002, 80, 670-678. [CrossRef] [PubMed]

76. Nordal, R.A.; Wong, C.S. Molecular targets in radiation induced blood-brain barrier disruption. Int. J. Radiat. Oncol. Biol. Phys. 2005, 62, 279-287. [CrossRef] [PubMed]

77. Baker, D.G.; Krochak, R.J. The response of the microvascular system to radiation: A review. Cancer Investig. 1989, 7, 287-294. [CrossRef] [PubMed]

78. Delattre, J.Y.; Shapiro, W.R.; Posner, J.B. Acute effects of low-dose cranial irradiation on regional capillary permeability in experimental brain tumors. J. Neurol. Sci. 1989, 90, 147-153. [CrossRef]

79. Bernstein, M.; Marotta, T.; Stewart, P.; Glen, J.; Resch, L.; Henkelman, M. Brain damage from 125I brachytherapy evaluated by MR imaging, a blood-brain barrier tracer, and light and electron microscopy in a rat model. J. Neurosurg. 1990, 73, 585-593. [CrossRef] [PubMed]

80. Groothuis, D.R.; Wright, D.C.; Ostertag, C.B. The effect of $125 \mathrm{I}$ interstitial radiotherapy on blood-brain barrier function in normal canine brain. J. Neurosurg. 1987, 67, 895-902. [CrossRef]

81. D'Avella, D.; Cicciarello, R.; Albiero, F.; Mesiti, M.; Gagliardi, M.E.; Russi, E.; D'Aquino, A.; Tomasello, F.; D'Aquino, S. Quantitative study of blood-brain barrier permeability changes after experimental whole-brain radiation. Neurosurgery 1992, 30, 30-34. [CrossRef]

82. Paulsson, M. Basement membrane proteins: Structure, assembly, and cellular interactions. Crit. Rev. Biochem. Mol. Biol. 1992, 27, 93-127.

83. Tilling, T.; Engelbertz, C.; Decker, S.; Korte, D.; Hüwel, S.; Galla, H.J. Expression and adhesive properties of basement membrane proteins in cerebral capillary endothelial cell cultures. Cell Tissue Res. 2002, 310, 19-29. [CrossRef]

84. Strup-Perrot, C.; Vozenin-Brotons, M.C.; Vandamme, M.; Linard, C.; Mathé, D. Expression of matrix metalloproteinases and tissue inhibitor metalloproteinases increases in X-irradiated rat ileum despite the disappearance of CD8a T cells. World J. Gastroenterol. 2005, 11, 6312-6321. [CrossRef]

85. Kim, Y.S.; Joh, T.H. Matrix metalloproteinases, new insights into the understanding of neurodegenerative disorders. Biomol. Ther. 2012, 20, 133-143. [CrossRef] [PubMed]

86. Planas, A.M.; Solé, S.; Justicia, C. Expression and activation of matrix metalloproteinase-2 and -9 in rat brain after transient focal cerebral ischemia. Neurobiol. Dis. 2001, 8, 834-846. [CrossRef] [PubMed]

87. Visse, R.; Nagase, H. Matrix metalloproteinases and tissue inhibitors of metalloproteinases: Structure, function, and biochemistry. Circ. Res. 2003, 92, 827-839. [CrossRef] [PubMed]

88. Aoudjit, F.; Masure, S.; Opdenakker, G.; Potworowski, E.F.; StPierre, Y. Gelatinase B (MMP-9), but not its inhibitor (TIMP1), dictates the growth rate of experimental thymic lymphoma. Int. J. Cancer 1999, 82, 743-747. [CrossRef]

89. Sellner, J.; Leib, S.L. In bacterial meningitis cortical brain damage is associated with changes in parenchymal MMP-9/TIMP1 ratio and increased collagen type IV degradation. Neurobiol. Dis. 2006, 21, 647-656. [CrossRef]

90. Giannelli, G.; Bergamini, C.; Marinosci, F.; Fransvea, E.; Quaranta, M.; Lupo, L.; Schiraldi, O.; Antonaci, S. Clinical role of MMP-2/TIMP-2 imbalance in hepatocellular carcinoma. Int. J. Cancer 2002, 97, 425-431. [CrossRef]

91. Gardner, J.; Ghorpade, A. Tissue inhibitor of metalloproteinase (TIMP)-1: The TIMPed balance of matrix metalloproteinases in the central nervous system. J. Neurosci. Res. 2003, 74, 801-806. [CrossRef]

92. Yang, K.; Liu, L.; Zhang, T.; Wu, G.; Ruebe, C.; Ruebe, C.; Hu, Y. TGF-betal transgenic mouse model of thoracic irradiation: Modulation of MMP-2 and MMP-9 in the lung tissue. J. Huazhong Univ. Sci. Technol. Med. Sci. 2006, 26, 301-304. 
93. Yang, K.; Palm, J.; König, J.; Seeland, U.; Rosenkranz, S.; Feiden, W.; Rübe, C.; Rübe, C.E. Matrix-Metallo-Proteinases and their tissue inhibitors in radiation-induced lung injury. Int. J. Radiat. Biol. 2007, 83, 665-676. [CrossRef]

94. Hovdenak, N.; Wang, J.; Sung, C.C.; Kelly, T.; Fajardo, L.F.; Hauer-Jensen, M. Clinical significance of increased gelatinolytic activity in the rectal mucosa during external beam radiation therapy of prostate cancer. Int. J. Radiat. Oncol. Biol. Phys. 2002, 53, 919-927. [CrossRef]

95. Araya, J.; Maruyama, M.; Sassa, K.; Fujita, T.; Hayashi, R.; Matsui, S.; Kashii, T.; Yamashita, N.; Sugiyama, E.; Kobayashi, M. Ionizing radiation enhances matrix metalloproteinase-2 production in human lung epithelial cells. Am. J. Physiol. Lung Cell Mol. Physiol. 2001, 280, L30-L38. [CrossRef] [PubMed]

96. Zhao, W.; Goswami, P.C.; Robbins, M.E. Radiation-induced up-regulation of Mmp2 involves increased mRNA stability, redox modulation, and MAPK activation. Radiat. Res. 2004, 161, 418-429. [CrossRef] [PubMed]

97. Nirmala, C.; Jasti, S.L.; Sawaya, R.; Kyritsis, A.P.; Konduri, S.D.; AliOsman, F.; Rao, J.S.; Mohanam, S. Effects of radiation on the levels of MMP-2, MMP-9 and TIMP-1 during morphogenic glial-endothelial cell interactions. Int. J. Cancer 2000, 88, 766-771. [CrossRef]

98. Garcia-Alloza, M.; Prada, C.; Lattarulo, C.; Fine, S.; Borrelli, L.A.; Betensky, R.; Greenberg, S.M.; Frosch, M.P.; Bacskai, B.J. Matrix metalloproteinase inhibition reduces oxidative stress associated with cerebral amyloid angiopathy in vivo in transgenic mice. J. Neurochem. 2009, 109, 1636-1647. [CrossRef] [PubMed]

99. Barnett, J.M.; McCollum, G.W.; Fowler, J.A.; Duan, J.J.; Kay, J.D.; Liu, R.Q.; Bingaman, D.P.; Penn, J.S. Pharmacologic and genetic manipulation of MMP-2 and -9 affects retinal neovascularization in rodent models of OIR. Investig. Ophthalmol. Vis. Sci. 2007, 48, 907-915. [CrossRef]

100. Krishnamurthy, P.; Peterson, J.T.; Subramanian, V.; Singh, M.; Singh, K. Inhibition of matrix metalloproteinases improves left ventricular function in mice lacking osteopontin after myocardial infarction. Mol. Cell Biochem. 2009, 322, 53-62. [CrossRef]

101. Manda, K.; Ueno, M.; Moritake, T.; Anzai, K. Radiation induced cognitive dysfunction and cerebellar oxidative stress in mice: Protective effect of alpha-lipoic acid. Behav. Brain Res. 2007, 177, 7-14. [CrossRef]

102. Shirazi, A.; Ghobadi, G.; Ghazi-Khansari, M. A radiobiological review on melatonin: A novel radioprotector. J. Radiat. Res. 2007, 48, 263-272. [CrossRef]

103. Vigliani, M.C.; Sichez, N.; Poisson, M.; Delatore, J.Y. A prospective study of cognitive functions following conventional radiotherapy for supratentorial gliomas in young adults: 4-year results. Int. J. Radiat. Oncol. Biol. Phys. 1996, 35, 527-533. [CrossRef]

104. Abayomi, O.K. Pathogenesis of irradiation-induced cognitve dysfunction. Acta Oncol. 1996, 35, $659-693$. [CrossRef]

105. Pantoni, L.; Gorelick, P. Cerebral Small Vessel Disease, 1st ed.; Cambridge University Press: Cambridge, UK, 2014.

106. Xu, W.H. Large artery: An important target for cerebral small vessel diseases. Ann. Transl. Med. $2014,2,78$. [CrossRef] [PubMed]

107. Jani, B.I.; Rajkumar, C. Ageing and vascular ageing. Postgrad. Med. J. 2006, 82, 357-362. [CrossRef] [PubMed]

108. Salloway, S. Subcortical Vascular Dementia: Binswanger's and CADASIL; American Academy of Neurology (AAN): Honolulu, HI, USA, 2003; pp. 1-29.

109. Pantoni, L.; Garcia, J.H.; Gutierrez, J.A. Cerebral white matter is highly vulnerable to ischemia. Stroke 1996, 27, 1641-1647. [CrossRef]

110. Schmidt, R.; Schmidt, H.; Haybaeck, J.; Loitfelder, M.; Weis, S.; Cavalieri, M.; Seiler, S.; Enzinger, C.; Ropele, S.; Erkinjuntti, T.; et al. Heterogeneity in age-related white matter changes. Acta Neuropathol. 2011, 122, 171-185. [CrossRef] [PubMed]

111. Hommet, C.; Mondon, K.; Constans, T.; Beaufils, E.; DeSmidt, T.; Camus, V.; Cottier, J.-P. Review of cerebral microangiopathy and Alzheimer's disease: Relation between white matter hyperintensities and microbleeds. Dement. Geriatr. Cogn. Disord. 2011, 32, 367-378. [CrossRef] [PubMed]

112. Moritz, A.R.; Oldt, M.R. Arteriolar sclerosis in hypertensive and non-hypertensive individuals. Am. J. Pathol. 1937, 13, 679-728.7. [PubMed]

113. Lodder, J.; Bamford, J.M.; Sandercock, P.A.; Jones, L.N.; Warlow, C.P. Are hypertension or cardiac embolism likely causes of lacunar infarction? Stroke 1990, 21, 375-381. [CrossRef] [PubMed]

114. Munoz, D.; Hastak, S.M.; Harper, B.; Lee, D.; Hachinski, V.C. Pathologic correlates of increased signals of the centrum ovale on magnetic resonance imaging. Arch. Neurol. 1993, 50, 492-497. [CrossRef] [PubMed] 
115. Mirski, M.A. Pharmacology of Blood Pressure Management during Cerebral Ischemia; American Academy of Neurology: Miami, FL, USA, 2005; pp. 456-469.

116. Wallin, A.; Blennow, K.; Gottfries, C.G. Neurochemical abnormalities in vascular dementia. Dementia 1989, 1, 120-130.

117. Caruso, P.; Signori, R.; Moretti, R. Small vessel disease to subcortical dementia: A dynamic model, which interfaces aging, cholinergic dysregulation and the neurovascular unit. Vasc. Health Risk Manag. 2019, 15, 259-281. [CrossRef]

118. Bohnen, N.I.; Muller, M.L.T.M.; Kuwabara, H.; Ocnstantien, G.M.; Studentski, S.A. Age-associated leukoaraiosis and cortical cholinergic deafferentation. Neurology 2009, 72, 1411-1416. [CrossRef] [PubMed]

119. Román, G.C. Brain hypoperfusion: A critical factor in vascular dementia. Neurol. Res. 2004, 26, 454-458. [CrossRef] [PubMed]

120. Zhan, S.S.; Beyreuther, K.; Schmitt, H.P. Synaptophysin immunoreactivity of the cortical neuropil in vascular dementia of Binswanger type compared with the dementia of Alzheimer type and non-demented controls. Dementia 1994, 5, 79-87. [CrossRef] [PubMed]

121. Ahtiluoto, S.; Polvikoski, T.; Peltonen, M.; Solomon, A.; Tuomilehto, J.; Winblad, B.; Sulkava, R.; Kivipelto, M. Diabetes, Alzheimer disease, and vascular dementia: A population-based neuropathologic study. Neurology 2010, 75, 1195-1202. [CrossRef]

122. Zhang, E.T.; Inman, C.B.; Weller, R.O. Interrelationships of the pia mater and the perivascular (Wirchov-Robin) spaces in the human cerebrum. J. Anat. 1990, 170, 111-123.

123. McNeely, A.A.; Ramirez, J.; Nestor, S.M.; Zhao, J.; Gao, F.; Kiss, A.; Stuss, D.T.; Black, S.E. Cholinergic subcortical hyperintensities in Alzheimer's disease patients from the Sunnybrook Dementia Study: Relationships with cognitive dysfunction and hippocampal atrophy. J. Alzheimers Dis. 2015, 43, 785-796. [CrossRef]

124. Sweeney, M.D.; Sagare, A.P.; Zlokovic, B.V. Blood-brain barrier breakdown in Alzheimer disease and other neurodegenerative disorders. Nat. Rev. Neurol. 2018, 14, 133-150. [CrossRef]

125. Abbott, N.J.; Pizzo, M.E.; Preston, J.E.; Janigro, D.; Thorne, R.G. The role of brain barriers in fluid movement in the CNS: Is there a 'glymphatic' system? Acta Neuropathol. 2018, 135, 387-407. [CrossRef]

126. Garcia, J.H.; Lassen, N.A.; Weiller, C.; Sperling, B.; Nakagawara, J. Ischemic stroke and incomplete infarction. Stroke 1996, 27, 761-765. [CrossRef]

127. Huijts, M.; Duits, A.; Staals, J.; Kroon, A.; Leeuw, P.; Oostenbrugge, R. Basal ganglia enlarged perivascular spaces are linked to cognitive function in patients with cerebral small vessel disease. Curr. Neurovascular Res. 2014, 11, 136-141. [CrossRef]

128. Dalkara, T.; Alarcon-Martinez, L. Cerebral micro-vascular signaling in health and disease. Brain Res. 2015, 14, 3-17. [CrossRef]

129. Giannakopoulos, P.; Gold, G.; Kövari, E.; Von Gunten, A.; Imhof, A.; Bouras, C.; Hof, P.R. Assessing the cognitive impact of Alzheimer disease pathology and vascular burden in the aging brain: The Geneva experience. Acta Neuropathol. 2007, 113, 1-12. [CrossRef] [PubMed]

130. Launer, L.J.; Hughes, T.M.; White, L.R. Microinfarcts, brain atrophy, and cognitive function: The Honolulu Asia Aging Study Autopsy Study. Ann. Neurol. 2011, 70, 774-780. [CrossRef] [PubMed]

131. Englund, E.A.; Person, B. Correlations between histopathologic white matter changes and proton MR relaxation times in dementia. Alzheimer Dis. Assoc. Disord. 1987, 1, 156-170. [CrossRef] [PubMed]

132. Román, G.C. Senile dementia of the Binswanger type: A vascular form of dementia in the elderly. JAMA 1987, 258, 1782-1788. [CrossRef] [PubMed]

133. Vinters, H.V.; Ellis, W.G.; Zarow, C.; Zaias, B.W.; Jagust, W.J.; Mack, W.J.; Chui, H.C. Neuropathological substrate of ischemic vascular dementia. J. Neuropathol. Exp. Neurol. 2000, 59, 931-945. [CrossRef]

134. Moody, D.M.; Brown, W.R.; Challa, V.R.; Anderson, R.L. Periventricular venous collagenosis: Association with leukoaraiosis. Radiology 1995, 194, 469-476. [CrossRef]

135. O'Brien, J.T.; Thomas, A. Vascular dementia. Lancet 2015, 386, 1698-1706. [CrossRef]

136. Wakita, H.; Tomimoto, H.; Akiguchi, I.; Kimura, J. Glial activation and white matter changes in the rat brain induced by chronic cerebral hypoperfusion: An immunoistochemical study. Acta Neuropathol. 1994, 87, 484-492. [CrossRef] 
137. Farkas, E.; Donka, G.; de Vous, R.A.I.; Mihaly, A.; Bari, F.; Luiten, P.G.M. Experimental cerebral hypoeprfusion induces white matter injury and microglial activation in the rat brain. Acta Neuropathol. 2004, 108, 57-64. [CrossRef]

138. Zhang, Z.G.; Bower, L.; Zhang, R.L.; Chen, S.; Windham, J.P.; Chopp, M. Three dimensional measurement of cerebral microvascular plasma perfusion, glial fibrillary acid protein and microtubule associated P-2 immunoreactivity after embolic stroke in rats: A double fluorescent labeled laser scanning confocal microscopic study. Brain Res. 1999, 844, 55-66. [CrossRef]

139. Tomimoto, H.; Akiguchi, I.; Wakita, H.; Svenaga, T.; Nakamura, S.; Kimura, J. Regressive changes of astroglia in white matter lesions in cerebrovascular disease and AD patients. Acta Neuropathol. 1997, 94, 146-152. [CrossRef]

140. Iadecola, C. The pathobiology of vascular dementia. Neuron 2013, 80, 844-866. [CrossRef] [PubMed]

141. Filous, A.S.; Silver, J. Targeting astrocytes in CNS injury and disease: A translational research approach. Prog. Neurobiol. 2016, 144, 173-187. [CrossRef]

142. Chen, A.; Akinyemi, R.O.; Hase, Y.; Firbank, M.J.; Ndung'U, M.N.; Foster, V.; Craggs, L.J.L.; Washida, K.; Okamoto, Y.; Thomas, A.J.; et al. Frontal white matter hyperintensities, clasmatodendrosis and gliovascular abnormalities in ageing and post-stroke dementia. Brain 2016, 139, 242-258. [CrossRef] [PubMed]

143. Moretti, R.; Caruso, P. Small Vessel Disease-Related Dementia: An Invalid Neurovascular Coupling? Int. J. Mol. Sci. 2020, 21, 1095. [CrossRef] [PubMed]

144. Zlokovic, B.V. Neurovascular pathways to neurodegeneration in Alzheimer's disease and other disorders. Nat. Rev. Neurosci. 2011, 12, 723-728. [CrossRef]

145. Cai, W.; Zhang, K.; Li, P.; Zhu, L.; Xu, J.; Yang, B.; Hu, X.; Lu, Z.; Chen, J. Dysfunction of the neurovascular unit in ischemic stroke and neurodegenerative diseases: An aging effect. Ageing Res. Rev. 2017, 34, 77-87. [CrossRef]

146. Prisby, R.D.; Ramsey, M.W.; Behnke, B.J.; Dominguez, J.M.; Donato, A.J.; Allen, M.R.; Delp, M.D. Aging reduces skeletal blood flow endothelium dependent vasodilation, and NO bioavailability in Rats. J. Bone Miner. Res. 2007, 22, 1280-1288. [CrossRef]

147. Nicholson, W.T.; Vaa, B.; Hesse, C.; Eisenach, J.H.; Joyner, M.J. Aging is associated with reduced prostacyclin-mediated dilation in the human forearm. Hypertenison 2009, 53, 973-978. [CrossRef]

148. Long, D.A.; Newaz, M.A.; Prabahakar, S.S.; Price, K.L.; Truong, L.; Feng, L.; Mu Oyekan, A.O.; Johnson, R.J. Loss of nitric oxide and endothelial-derived hyperpolarizing factor-mediated responses in ageing. Kidney Int. 2005, 68, 2154-2163. [CrossRef] [PubMed]

149. Van der Loo, B.; Labugger, R.; Skepper, J.N.; BAchschmid, M.; Kilo, J.; Powell, J.M.; Palacios-Callendere, M.; Erusalimsky, J.D.; Quaschning, T.; Malinski, T. Enhanced peroxynitrite formation is associated with vascular ageing. J. Exp. Med. 2000, 192, 1731-1744. [CrossRef] [PubMed]

150. Puca, A.A.; Carrizzo, A.; Ferrario, A.; Villa, F.; Vecchione, C. Endothelial nitric oxide synthase, vascular integrity and human exceptional longevity. Immun. Ageing 2012, 9, 26. [CrossRef]

151. Flentje, A.; Kalsi, R.; Monahan, T.S. Small GTPases and Their Role in Vascular Disease. Int. J. Mol. Sci. 2019, 20, 917. [CrossRef] [PubMed]

152. Hartmann, S.; Ridley, A.J.; Lutz, S. The Function of Rho-Associated Kinases ROCK1 and ROCK2 in the Pathogenesis of Cardiovascular Disease. Front. Pharmacol. 2015, 6, 276. [CrossRef] [PubMed]

153. Pestonjamasp, K.; Amieva, M.R.; Strassel, C.P.; Nauseef, W.M.; Furthmayr, H.; Luna, E.J. Moesin, ezrin, and p205 are actin-binding proteins associated with neutrophil plasma membranes. Mol. Biol. Cell 1995, 6, 247-259. [CrossRef]

154. Van Nieuw Amerongen, G.P.; Koolwijk, P.; Versteilen, A.; van Hinsbergh, V.W. Involvement of RhoA/Rho kinase signaling in VEGF-induced endothelial cell migration and angiogenesis in vitro. Arterioscler. Thromb. Vasc. Biol. 2003, 23, 211-217. [CrossRef]

155. Matsumoto, Y.; Uwatoku, T.; Oi, K.; Abe, K.; Hattori, T.; Morishige, K.; Eto, Y.; Fukumoto, Y.; Nakamura, K.-I.; Shibata, Y.; et al. Long-term inhibition of Rho-kinase suppresses neointimal formation after stent implantation in porcine coronary arteries: Involvement of multiple mechanisms. Arterioscler. Thromb. Vasc. Biol. 2004, 24, 181-186. [CrossRef]

156. Szulcek, R.; Beckers, C.M.; Hodzic, J.; de Wit, J.; Chen, Z.; Grob, T.; Musters, R.J.; Minshall, R.D.; van Hinsbergh, V.W.; van Nieuw Amerongen, G.P. Localized RhoA GTPase activity regulates dynamics of endothelial monolayer integrity. Cardiovasc. Res. 2013, 99, 471-482. [CrossRef] 
157. Van Nieuw Amerongen, G.P.; Beckers, C.M.; Achekar, I.D.; Zeeman, S.; Musters, R.J.; van Hinsbergh, V.W. Involvement of Rho kinase in endothelial barrier maintenance. Arterioscler. Thromb. Vasc. Biol. 2007, 27, 2332-2339. [CrossRef]

158. Drake, C.T.; Iadecola, C. The role of the neuronal signaling in controlling cerebral blood flow. Brain Lang. 2007, 102, 141-152. [CrossRef] [PubMed]

159. Schmidt, R.; Seiler, S.; Loitfelder, M. Longitudinal change of small-vessel disease-related brain abnormalities. J. Cereb Blood Flow Metab. 2016, 36, 26-39. [CrossRef] [PubMed]

160. Chitnis, T.; Weiner, H.L. CNS inflammation and neurodegeneration. J. Clin. Investig. 2017, 127, $3577-3587$. [CrossRef] [PubMed]

161. Kiechle, T.; Dedeoglu, A.; Kubilus, J.; Kowall, N.W.; Beal, M.F.; Friedlander, R.M.; Hersch, S.M.; Ferrante, R.J. Cytochrome C and caspase-9 expression in Huntington's disease. Neuromol. Med. 2002, 1, 183-195. [CrossRef]

162. Pasinelli, P.; Houseweart, M.K.; Brown, R.H.; Cleveland, D.W. Caspase-1 and -3 are sequentially activated in motor neuron death in $\mathrm{Cu}, \mathrm{Zn}$ superoxide dismutase-mediated familial amyotrophic lateral sclerosis. Proc. Natl. Acad. Sci. USA 1998, 95, 13901-13906. [CrossRef]

163. Ito, Y.; Ofengeim, D.; Najafov, A.; Das, S.; Saberi, S.; Li, Y.; Hitomi, J.; Zhu, H.; Chen, H.; Mayo, L.; et al. RIPK1 mediates axonal degeneration by promoting inflammation and necroptosis in ALS. Science 2016, 353, 603-608. [CrossRef]

164. Ofengeim, D.; Ito, Y.; Najafov, A.; Zhang, Y.; Shan, B.; DeWitt, J.P.; Ye, J.; Zhang, X.; Chang, A.; Vakifahmetoglu-Norberg, H.; et al. Activation of necroptosis in multiple sclerosis. Cell Rep. 2015, 10, 1836-1849. [CrossRef]

165. Shi, Z.W.; Sha Ge, L.; Li, Y.C. The Role of Necroptosis in Cardiovascular Disease. Front. Pharmacol. 2018, 9, 721. [CrossRef]

166. Perry, V.H.; Cunningham, C.; Holmes, C. Systemic infections and inflammation affect chronic neurodegeneration. Nat. Rev. Immunol. 2007, 7, 161-167. [CrossRef]

167. Dinan, T.G.; Cryan, J.F. Gut instincts: Microbiota as a key regulator of brain development, aging, and neurodegeneration. J. Physiol. 2017, 595, 489-503. [CrossRef]

168. Quigley, E.M. Microbiota-brain-gut axis and neurodegenerative disease. Curr. Neurol. Neurosci. Rep. 2017, 17, 94. [CrossRef]

169. Chen, I.; Chia, N.; Kalari, K.R.; Yao, J.Z.; Novotvna, M.; Soldan, M.M.; Luckey, D.H.; Marietta, E.V.; Jeraldo, P.R.; Chen, X.; et al. Multiple Sclerosis patients have a distinct gut microbiota compared to healthy controls. Sci. Rep. 2016, 6, 28484. [CrossRef] [PubMed]

170. Andreadou, E.; Pantazaki, A.A.; Danilidou, M.; Tsolaki, M. rhamnolipids, microbial virulence factors in Alzheimer's disease. J. Alzheimer's Dis. 2017, 59, 209-222. [CrossRef] [PubMed]

171. Goldman, S.M.; Kamel, F.; Rose, G.W.; Jewell, S.A.; Marras, C.; Hopper, J.A.; Umbach, D.M.; Bhudhikanok, G.S.; Meng, C.; Korell, M.; et al. Peptydologlycan recognition protein genes and risk of Parkinson's Disease. Mov. Disord. 2014, 29, 1171-1180. [CrossRef] [PubMed]

172. Franceschi, C.; Bonafe', M.; Valensin, S.; Olivieri, F.; De Luca, M.; Ottaviani, E.; De Benedictis, G. Inflamm-aging: An evolutionary perspective on immunoscence. Ann. N. Y. Acad. Sci. 2000, 908, 244-254. [CrossRef] [PubMed]

173. Stephenson, J.; Nutma, E.; van der Valk, P.; Amor, S. Inflammation in CNS neurodegenerative diseases. Immunology 2018, 154, 204-219. [CrossRef]

174. Ynakner, B.A.; Lu, T.; Loerch, P. The aging brain. Ann. Rev. Pathol. 2008, 3, 41-66. [CrossRef]

175. Rawji, K.S.; Mishra, M.K.; Michaels, N.J.; Rivest, S.; Stys, P.K.; Yong, V.W. Immunosenescence of microglia and macrophage impact on aging central nervous system. Brain 2016, 139, 653-661. [CrossRef]

176. Chinta, S.J.; Woods, G.; Rane, A.; Demaria, M.; Campisi, J.; Andersen, J.K. Cellular senescence and the aging brain. Exp. Gerontol. 2015, 68, 3-7. [CrossRef]

177. De Silva, T.M.; Brait, V.H.; Drummond, G.R.; Sobey, C.G.; Miller, A.A. Nox2 oxidase activity accounts for the oxidative stress and vasomotor dysfunction in mouse cerebral arteries following ischemic stroke. PLoS ONE 2011, 6, e28393. [CrossRef]

178. Dong, Y.-F.; Kataoka, K.; Toyama, K.; Sueta, D.; Koibuchi, N.; Yamamoto, E.; Yata, K.; Tomimoto, H.; Ogawa, H.; Kim-Mitsuyama, S. Attenuation of brain damage and cognitive impairment by direct renin inhibition in mice with chronic cerebral hypoperfusion. Hypertension 2011, 58, 635-642. [CrossRef] 
179. Xie, H.; Ray, P.E.; Short, B.L. NF-kappa B activation plays a role in superoxide-mediated cerebral endothelial dysfunction after hypoxia/reoxygenation. Stroke 2005, 36, 1047-1052. [CrossRef]

180. Didion, S.P.; Lynch, C.M.; Baumbach, G.L.; Faraci, F.M. Impaired Endothelium-Dependent Responses and Enhanced Influence of Rho-Kinase in Cerebral Arterioles in Type II Diabetes. Stroke 2005, 36, 342-347. [CrossRef] [PubMed]

181. Zhang, X.; Wu, B.; Nie, K.; Jia, Y.; Yu, J. Effects of acupuncture on declined cerebral blood flow, impaired mitochondrial respiratory function and oxidative stress in multi-infarct dementia rats. Neurochem. Int. 2014, 65, 23-29. [CrossRef] [PubMed]

182. Huang, J.L.; Fu, S.T.; Jiang, Y.Y.; Cao, Y.B.; Guo, M.L.; Wang, Y.; Xu, Z. Protective effects of Nicotiflorin on reducing memory dysfunction, energy metabolism failure, and oxidative stress in multi-infarct dementia model rats. Pharmacol. Biochem. Behav. 2007, 86, 741-748. [CrossRef] [PubMed]

183. Liu, H.; Zhang, J. Cerebral hypoperfusion and cognitive impairment: The pathogenic role of vascular oxidative stress. Int. J. Neurosci. 2012, 122, 494-499. [CrossRef] [PubMed]

184. Halliwell, B. Role of free radicals in the neurodegenerative diseases: Therapeutic implications for antioxidant treatment. Drugs Aging 2001, 18, 685-716. [CrossRef]

185. Lin, M.T.; Beal, M.F. Mitochondrial dysfunction and oxidative stress in neurodegenerative diseases. Nature 2006, 443, 787-795. [CrossRef]

186. Flanary, O.E.; Sammons, N.W.; Nguyen, C.; Walker, D.; Streit, W.J. Evidence that aging and amyloid promote microglial cell senescence. Rejuvenation Res. 2007, 10, 61-74. [CrossRef]

187. De Silva, T.M.; Miller, A.A. Cerebral small vessel disease: Targeting oxidative stress as a novel therapeutic strategy. Front. Pharmacol. 2016, 7. [CrossRef]

188. Bath, P.M.; Wardlaw, J.M. Pharmacological treatment and prevention of cerebral small vessel disease: A review of potential interventions. Int. J. Stroke 2015, 10, 469-478. [CrossRef] [PubMed]

189. Poggesi, A.; Pasi, M.; Pescini, F.; Pantoni, L.; Inzitari, D. Circulating biologic markers of endothelial dysfunction in cerebral small vessel disease: A review. J. Cereb. Blood Flow Metab. 2016, 36, 72-94. [CrossRef] [PubMed]

190. Bullen, M.L.; Miller, A.A.; Andrews, K.L.; Irvine, J.C.; Ritchie, R.H.; Sobey, C.G.; Kemp-Harper, B.K. Nitroxyl (HNO) as a vasoprotective signaling molecule. Antioxid. Redox Signal. 2011, 14, 1675-1686. [CrossRef] [PubMed]

191. Miller, A.A.; Maxwell, K.F.; Chrissobolis, S.; Bullen, M.L.; Ku, J.M.; De Silva, T.; Selemidis, S.; Hooker, E.U.; Drummond, G.R.; Sobey, C.G.; et al. Nitroxyl (HNO) suppresses vascular Nox2 oxidase activity. Free Radic. Biol. Med. 2013, 60, 264-271. [CrossRef] [PubMed]

192. Drummond, G.R.; Selemidis, S.; Griendling, K.K.; Sobey, C.G. Combating oxidative stress in vascular disease: NADPH oxidases as therapeutic targets. Nat. Rev. Drug Discov. 2011, 10, 453-471. [CrossRef]

193. Gopalan, Y.; Shuaib, I.L.; Magosso, E.; Ansari, M.A.; Abu Bakar, M.R.; Wong, J.W.; Khan, N.A.; Liong, W.C.; Sundram, K.; Ng, B.H.; et al. Clinical investigation of the protective effects of palm vitamin $\mathrm{E}$ tocotrienols on brain white matter. Stroke 2014, 45, 1422-1428. [CrossRef]

194. Ueno, Y.; Koike, M.; Shimada, Y.; Shimura, H.; Hira, K.; Tanaka, R.; Uchiyama, Y.; Hattori, N.; Urabe, T. L-carnitine enhances axonal plasticity and improves white-matter lesions after chronic hypoperfusion in the rat brain. J. Cereb. Blood Flow Metabol. 2015, 35, 382-391. [CrossRef]

195. Study Collaborative, G. MRC/BHF heart protection study of antioxidant vitamin supplementation in 20,536 high-risk individuals: A randomized placebo-controlled trial. Lancet 2002, 360, 23-33. [CrossRef]

196. Moretti, R.; Dal Ben, M.M.; Gazzin, S.; Tiribelli, C. Homocysteine in Neurology: From Endothelium to Neurodegeneration. Curr. Nutr. Food Sci. 2017, 13, 163-175. [CrossRef]

197. Modrick, M.L.; Didion, S.P.; Sigmund, C.D.; Faraci, F.M. Role of oxidative stress and AT1 receptors in cerebral vascular dysfunction with aging. Am. J. Physiol. Heart Circ. Physiol. 2009, 296, H1914-H1919. [CrossRef]

198. Han, B.H.; Zhou, M.L.; Johnson, A.W.; Singh, I.; Liao, F.; Vellimana, A.K.; Nelson, J.W.; Milner, E.; Cirrito, J.R.; Basak, J.; et al. Contribution of reactive oxygen species to cerebral amyloid angiopathy, vasomotor dysfunction, and microhemorrhage in aged Tg2576 mice. Proc. Natl. Acad. Sci. USA 2015, 112, E881-E890. [CrossRef] [PubMed]

199. Allen, C.L.; Bayraktutan, U. Oxidative stress and its role in the pathogenesis of ischaemic stroke. Int. J. Stroke 2009, 4, 461-470. [CrossRef] [PubMed] 
200. Altenhofer, S.; Radermacher, K.A.; Kleikers, P.W.; Wingler, K.; Schmidt, H.H. Evolution of NADPH oxidase inhibitors: Selectivity and mechanisms for target engagement. Antioxid. Redox Signal. 2015, 23, 406-427. [CrossRef] [PubMed]

201. Bedard, K.; Whitehouse, S.; Jaquet, V. Challenges progress, and promises for developing future NADPH oxidase therapeutics. Antioxid. Redox Signal. 2015, 23, 355-357. [CrossRef]

202. Stuehr, D.J.; Fasehun, O.A.; Kwon, N.S.; Gross, S.S.; Gonzalez, J.A.; Levi, R.; Nathan, C.F. Inhibition of macrophage and endothelial cell nitric oxide synthase by diphenyleneiodonium and its analogs. FASEB J. 1991, 5, 98-103. [CrossRef]

203. O'Donnell, B.V.; Tew, D.G.; Jones, O.T.; England, P.J. Studies on the inhibitory mechanism of iodonium compounds with special reference to neutrophil NADPH oxidase. Biochem. J. 1993, 290, 41-49. [CrossRef]

204. Vejrazka, M.; Micek, R.; Stipek, S. Apocynin inhibits NADPH oxidase in phagocytes but stimulates ROS production in non-phagocytic cells. Biochim. Biophys. Acta 2005, 1722, 143-147. [CrossRef]

205. Rey, F.E.; Cifuentes, M.E.; Kiarash, A.; Quinn, M.T.; Pagano, P.J. Novel competitive inhibitor of NAD(P)H oxidase assembly attenuates vascular $\mathrm{O}(2)(-)$ and systolic blood pressure in mice. Circ. Res. 2001, 89, 408-414. [CrossRef]

206. Sun, Q.A.; Hess, D.T.; Wang, B.; Miyagi, M.; Stamler, J.S. Off-target thiol alkylation by the NADPH oxidase inhibitor 3-benzyl-7-(2-benzoxazolyl)thio-1,2,3-triazolo[4,5-d]pyrimidine (VAS2870). Free Radic. Biol. Med. 2012, 52, 1897-1902. [CrossRef]

207. Laleu, B.; Gaggini, F.; Orchard, M.; Fioraso-Cartier, L.; Cagnon, L.; Houngninou-Molango, S.; Gradia, A.; Duboux, G.; Merlot, C.; Heitz, F.; et al. First in class, potent, and orally bioavailable NADPH oxidase isoform 4 (Nox4) inhibitors for the treatment of idiopathic pulmonary fibrosis. J. Med. Chem. 2010, 53, 7715-7730. [CrossRef]

208. Cayatte, A.J.; Rupin, A.; Oliver-Krasinski, J.; Maitland, K.; Sansilvestri-Morel, P.; Boussard, M.F.; Wierzbicki, M.; Verbeuren, T.J.; Cohen, R.A. S17834, a new inhibitor of cell adhesion and atherosclerosis that targets NADPH oxidase. Arterioscler. Thromb. Vasc. Biol. 2001, 21, 1577-1584. [CrossRef] [PubMed]

209. Yamaguchi, T.; Sano, K.; Takakura, K.; Saito, I.; Shinohara, Y.; Asano, T.; Yasuhara, H. Ebselen in acute ischemic stroke: A placebo-controlled, double-blind clinical trial. Ebselen Study Group. Stroke 1998, 29, 12-17. [CrossRef] [PubMed]

210. Ulivi, L.; Maccarrone, M.; Giannini, N.; Ferrari, E.; Caselli, M.C.; Montano, V.; Chico, L.; Casani, A.; Navari, E.; Cerchiai, N.; et al. Oxidative Stress in Cerebral Small Vessel Disease Dizziness Patients, Basally and After Polyphenol Compound Supplementation. Curr. Mol. Med. 2018, 18, 160-165. [CrossRef] [PubMed]

211. Shi, L.; Adams, M.M.; Long, A.; Carter, C.C.; Bennett, C.; Sonntag, W.E.; Nicolle, M.M.; Robbins, M.; D'Agostino, R.; Brunso-Bechtold, J.K. Spatial learning and memory deficits after whole-brain irradiation are associated with changes in NMDA receptor subunits in the hippocampus. Radiat. Res. 2006, 166, 892-899. [CrossRef]

212. Dent, P.; Yacoub, A.; Fisher, P.B.; Hagan, M.P.; Grant, S. MAPK pathways in radiation responses. Oncogene 2003, 22, 5885-5896. [CrossRef]

213. Corn, B.W.; Moughan, J.; Knisely, J.P.S.; Fox, S.W.; Chakravarti, A.; Yung, W.K.A.; Curran, W.J., Jr.; Robins, H.I.; Brachman, D.G.; Henderson, R.H.; et al. Prospective evaluation of quality of life and neurocognitive effects in patients with multiple brain metastases receiving whole-brain radiotherapy with or without thalidomide on Radiation Therapy Oncology Group (RTOG) trial 0118. Int. J. Radiat Oncol. Biol. Phys. 2008, 71, 71-78. [CrossRef]

214. Hoang-Xuan, K.; Delattre, J.; Poisson, M. Complications nerveuses de la radiotherapie. Encycl. Méd. Chir. Neurol. Ed. Sci. Médicales Elsevier SAS Paris 1997, 17, 161.

215. Posner, J.B. Side effects of radiation therapy. In Neurologic Complications of Cancer; F. A. Davis Company: Philadelphia, PA, USA, 1995.

(C) 2020 by the authors. Licensee MDPI, Basel, Switzerland. This article is an open access article distributed under the terms and conditions of the Creative Commons Attribution (CC BY) license (http://creativecommons.org/licenses/by/4.0/). 